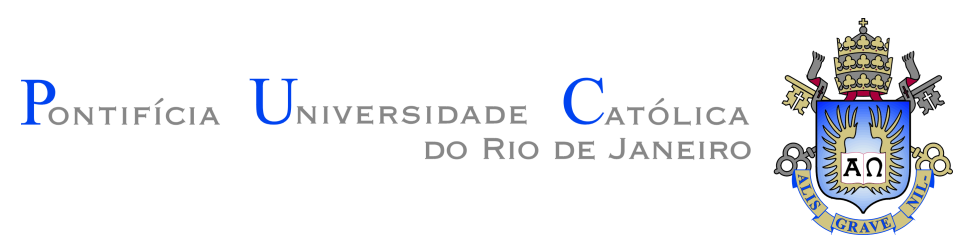

Alison Rocha de Farias

\title{
Unemployment Insurance and Labor Turnover: Evidence from Brazil
}

Dissertação de Mestrado

Dissertation presented to the Programa de Pós-graduação em Economia of the PUC-Rio in partial fulfillment of the requirements for the degree of Mestre em Economia .

Advisor : Prof. Gabriel Lopes de Ulyssea Co-advisor: Prof. Gustavo Maurício Gonzaga 


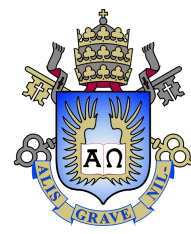

Alison Rocha de Farias

\section{Unemployment Insurance and Labor Turnover: Evidence from Brazil}

Dissertation presented to the Programa de Pós-graduação em Economia of the PUC-Rio in partial fulfillment of the requirements for the degree of Mestre em Economia. Approved by the undersigned Examination Committee.

Prof. Gabriel Lopes de Ulyssea

Advisor

Department of Economics - Oxford University

Prof. Gustavo Maurício Gonzaga

Co-advisor

Departamento de Economia - PUC-Rio

Prof. Juliano Junqueira Assunção

Departamento de Economia - PUC-Rio

Prof. Renata Del Tedesco Narita

Faculdade de Economia e Administração - USP

Prof. Augusto Cesar Pinheiro da Silva

Vice Dean of Graduate Studies

Centro de Ciências Sociais - PUC-Rio

Rio de Janeiro, September the 27th, 2018 
All rights reserved.

\section{Alison Rocha de Farias}

B.A., Economics, Universidade de Brasília (UnB-DF), 2014.

Bibliographic data

Rocha de Farias, Alison

Unemployment Insurance and Labor Turnover: Evidence from Brazil / Alison Rocha de Farias; advisor: Gabriel Lopes de Ulyssea; co-advisor: Gustavo Maurício Gonzaga. - Rio de janeiro: PUC-Rio, Departamento de Economia, 2018.

v., 61 f: il. color. ; $30 \mathrm{~cm}$

Dissertação (mestrado) - Pontifícia Universidade Católica do Rio de Janeiro, Departamento de Economia.

Inclui bibliografia

1. Economia - Teses. 2. Economia do Trabalho - Teses. 3. Fluxos de trabalhadores;. 4. Rotatividade;. 5. Seguro desemprego;. 6. Fluxo de entrada no desemprego;. 7. Elegibilidade ao seguro desemprego;. 8. Procura por emprego;. 9. Pedidos de demissão;. 10. Capital humano específico à firma;. 11. Produtividade do trabalho.. I. Ulyssea, Gabriel. II. Gonzaga, Gustavo. III. Pontifícia Universidade Católica do Rio de Janeiro. Departamento de Economia. IV. Título. 
To my parents, Antonio and Marlene, and my fianceé, Bruna, for their support and encouragement. 


\section{Acknowledgments}

First, I would like to thank my advisors Prof. Gabriel Ulyssea and Prof. Gustavo Gonzaga for their exquisite guidance and rich contribution to this research. I am also extremely grateful for their patience and understanding, without which I would not have finished this work.

Then, I wish to thank all the jury members Prof. Renata Del Tedesco Narita and Prof. Juliano Junqueira Assunção for accepting the invite to be in the Examination Committee.

I would also like to thank my family and my colleagues in PUC-Rio, who made the entire process much more joyful.

Finally, I wish to especially thank my beloved parents, Antonio and Marlene, for their lifelong dedication and sacrifice to raise me. They are true role models whose deeds I will never forget.

This study was financed in part by the Coordenação de Aperfeiçoamento de Pessoal de Nível Superior - Brasil (CAPES) - Finance Code 001. I am thankful to the Brazilian Ministry of Labor for granting me access to the RAIS (Relação Anual de Informações Sociais) database. 


\section{Abstract}

Rocha de Farias, Alison; Ulyssea, Gabriel (Advisor); Gonzaga, Gustavo (Co-Advisor). Unemployment Insurance and Labor Turnover: Evidence from Brazil. Rio de Janeiro, 2018. 61p. Dissertação de Mestrado - Departamento de Economia, Pontifícia Universidade Católica do Rio de Janeiro.

Recent studies estimate that eligibility for unemployment insurance program raises layoff probability by $12 \%$ in Brazil. This paper develops a partial equilibrium model where workers search for jobs and might quit them in order to collect UI benefits. We calibrate it using data from Brazil and use it to assess the consequences of this behavior on firmspecific human capital accumulation and labor productivity in the economy. Through counterfactual exercises, we find that a stricter job tenure eligibility threshold would raise the average wage, the job tenure, but also the turnover rate. We discuss this last result and conclude that it depends on how the policy modifies the fraction of employed workers who voluntarily separate from their jobs. In another exercise, we find a negative relationship between the change in the UI replacement rate and the average employment duration.

\section{Keywords}

Worker flows; Turnover; Unemployment insurance; Unemployment inflow; UI eligibility; Search; Quits; Firm-specific human capital; Labor productivity. 


\section{Resumo}

Rocha de Farias, Alison; Ulyssea, Gabriel; Gonzaga, Gustavo. Seguro Desemprego e Rotatividade do Trabalho: Evidências do Brasil. Rio de Janeiro, 2018. 61p. Dissertação de Mestrado Departamento de Economia, Pontifícia Universidade Católica do Rio de Janeiro.

Estudos recentes estimam que a elegibilidade ao programa de seguro desemprego aumenta a probabilidade de demissão em $12 \%$ no Brasil. Esse artigo desenvolve um modelo de equilíbrio parcial onde trabalhadores buscam por emprego e podem se demitir para coletar benefícios do seguro desemprego. Calibramo-lo usando dados do Brasil e o utilizamos para medir as consequências desse comportamento sobre o acúmulo de capital humano específico à firma e sobre a produtividade do trabalho na economia. Por meio de exercícios contrafactuais, descobrimos que tornar a elegibilidade ao seguro desemprego mais estrita aumentaria o salário médio, a estabilidade no emprego, mas também a taxa de rotatividade. Discutimos esse último resultado e concluímos que isso depende de como a política modifica a fração de trabalhadores empregados que voluntariamente se separam de seus empregos. Em outro exercício, encontramos uma relação negativa entre a mudança na taxa de reposição do programa de seguro desemprego e a duração média do emprego.

\section{Palavras-chave}

Fluxos de trabalhadores; Rotatividade; Seguro desemprego; Fluxo de entrada no desemprego; Elegibilidade ao seguro desemprego; Procura por emprego; Pedidos de demissão; Capital humano específico à firma; Produtividade do trabalho. 


\section{Table of contents}

1 Introduction $\quad 12$

2 Institutional Background, Data and Stylized Facts $\quad 16$

$\begin{array}{ll}2.1 & 16\end{array}$

$\begin{array}{ll}2.2 \text { Data } & 19\end{array}$

2.3 Stylized Facts 20

3 The model $\quad 24$

3.1 Timing of events 24

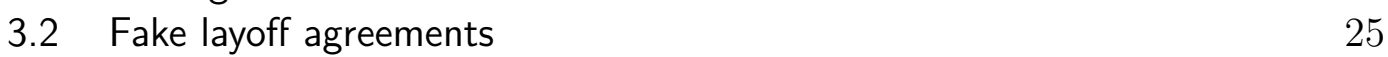

$\begin{array}{ll}\text { 3.3 Bellman Equations } & 27\end{array}$

3.3.1 Unemployment value function 27

$\begin{array}{ll}\text { 3.3.2 Layoff value function } & 27\end{array}$

$\begin{array}{ll}\text { 3.3.3 Agreement value function } & 27\end{array}$

$\begin{array}{ll}\text { 3.3.4 Employment value function } & 28\end{array}$

4 Calibration $\quad 29$

$\begin{array}{lll}4.1 & \text { Parameterization } & 29\end{array}$

4.2 Calibration Method 30

4.2.1 Moments and Identification 31

4.2.2 Parameters and Model fit 32

5 Counterfactual Analysis $\quad 37$

$\begin{array}{lll}5.1 & \text { Stricter eligibility } & 37\end{array}$

5.2 Homogeneous replacement rates 42

6 Conclusions $\quad 44$

$\begin{array}{lll}\text { A Data Appendix } & 49\end{array}$

B Calibration Appendix $\quad 50$

$\begin{array}{ll}\text { C Identification Appendix } & 53\end{array}$

D Simulation Appendix $\quad 54$

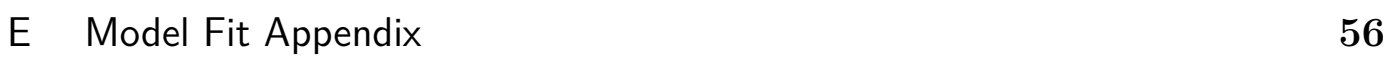

$\begin{array}{ll}\text { F } & \text { Turnover Mathematical Appendix }\end{array}$ 


\section{List of figures}

Figure 2.1 Kernel density estimation of wage/minimum wage distribution of formal employees in Brazil. RAIS, 2007-2010. Kernel function $=$ Gaussian, bandwidth $=.02$.

Figure 2.2 Replacement rate distribution of formal employees in Brazil. RAIS, 2007-2010.

Figure 2.3 Aggregate Separation hazard rate by job tenure of formal employees in Brazil. RAIS, 2007-2010.

Figure 2.4 Separation hazard rate by reason of separation by job tenure of formal employees in Brazil. RAIS, 2007-2010.

Figure 2.5 Termination without cause hazard rate by replacement rate by job tenure of formal employees in Brazil. RAIS, 2007-2010. 23

Figure 4.1 Replacement rate distribution of employed workers. $\quad 34$

Figure 4.2 Job tenure distribution of employed workers. 36

$\begin{array}{lll}\text { Figure 4.3 Termination without cause hazard function. } & 36\end{array}$

Figure 5.1 Scatter plot of the change in the fraction of the employed workers who voluntarily separate (quitters) of each cell versus their change in the average job tenure.

Figure 5.2 Scatter plot of the change in the turnover rate of each cell versus their change in the fraction of the employed workers who voluntarily separate (quitters).

Figure 5.3 Scatter plot of the change in the turnover rate of each cell versus their change in the average job tenure.

Figure 5.4 Hazard function of terminations without cause.

Figure C.1 Sensitivity of the objective function

Figure C.1 Sensitivity of the objective function

Figure E.1 Replacement rate distribution of employed workers. $\quad 56$

Figure E.2 Job tenure distribution of employed workers. 56

$\begin{array}{lll}\text { Figure E.3 Termination without cause hazard function. } & 57\end{array}$

Figure E.4 Termination without cause hazard function for the first 9 months of employment relation. 


\section{List of tables}

Table 4.1 Second step calibrated parameters. 34

Table 4.2 Moments fit. $\quad 35$

Table 5.1 Stricter eligibility threshold: 12 months. 39

Table 5.2 Homogeneous replacement rates: $80 \%$ and 50\%. 43

Table B.1 Transition parameters. PME 01/2007-12/2010. 51

Table B.2 Wage growth parameters, 18-25 years old. RAIS 2007-2010. 51

Table B.3 Wage growth parameters, 26-35 years old. RAIS 2007-2010. 52

Table B.4 Wage growth parameters, 36-49 years old. RAIS 2007-2010. 52

Table B.5 Initial wage offer distribution. RAIS 2007-2010. 52

Table D.1 90th percentile of the job tenure distribution of employed workers.

Table E.1 Turnover rate. $\quad 58$

Table E.2 Share of employed workers that quit (separate without agreement). 58 


\section{List of Abreviations}

UI - Unemployment Insurance

RAIS - Relações anuais de informações sociais

PME - Pesquisa Mensal do Emprego

IBGE - Instituto Brasileiro de Geografia e Estatística

SMM - Simulated Method of Moments

CBO - Classificação Brasileira de Ocupações

CLT - Consolidação das Leis de Trabalho

FGTS - Fundo de Garantia do Tempo de Serviço 


\section{Introduction}

Worker turnover is inherent to market economies, as employers and employees are free to pair or break ongoing job matches. Thus, it may manifest the productivity-enhancing process of factor reallocation [e.g., when workers move from dying low productivity units to more productive ones or when good quality matches are formed through some degree of assortative matching in the labor market (Lise et al., 2016; Foster et al., 2006). Care must be taken, though, when such process is not driven by market conditions for it may have some drawbacks. That is the case when economic regulation or labor market institutions take part in it (Walker, 2011; Martin and Scarpetta, 2012). For instance, there is evidence that employment protection rules decrease reallocation in the labor market, which raises the expected duration of unemployment spells and reduces the employment rate (Blanchard and Portugal, 2001; Haltiwanger et al., 2014; Davis and Haltiwanger, 2014).

The aim of this paper to shed some light on the relationship of the Unemployment Insurance (UI) design to worker turnover. Recent studies estimate that eligibility for UI program raises layoff probability by $12 \%$ in Brazil. ${ }^{12}$ This finding represents a rise in the unemployment inflow caused by non-market conditions and is, therefore, likely to be related to inefficiencies in the labor market, such as: (i) higher spending on redundancy costs; (ii) greater expenditure on vacancy-posting in equilibrium; (iii) less investment in training by employers; (iv) lower firm-specific human capital (FSHC) accumulation by workers. This paper sheds light on the role of UI as a determinant of worker turnover by developing a framework where workers may quit their jobs in

${ }^{1}$ Carvalho et al., 2018 and Doornik et al., 2018 exploit an unanticipated change in the Brazilian UI program eligibility criteria implemented in 2015. They use diff-in-diff to estimate the effect of eligibility for UI on the probability of unjustified dismissal using the same data source over similar sample periods [Carvalho et al., 2018 uses 2012-2015 and Doornik et al., 2018 uses 2013-2015]. Though Carvalho et al., 2018 use a 10\% random sample of workers, the results are quite similar, .55-.65pp increase in layoff probability, both consistent with strategic unemployment.

${ }^{2}$ Rebollo-Sanz, 2012 finds evidence on UI eligibility raising layoff probability in Spain. She estimates a multivariate mixed proportional hazard rate model using longitudinal data from the Social Security records on the individual level, the Longitudinal Working Lives Sample, and finds a significant increase on the layoff hazard rate as workers qualify for unemployment benefit. 
order to collect UI benefits and assessing the consequences on aggregate FSHC accumulation - item (iv) aforementioned - and labor productivity.

The paper makes two contributions. First, it adds up to the literature on labor market institutions and worker flows by studying the UI as one of the worker turnover determinants (e.g., de Barros et al., 2001; Bassanini et al., 2010; Jung and Kuhn, 2014), whereas the majority of the existing literature focuses on firing costs and employment protection rules (e.g., Kugler, 1999; Gonzaga et al., 2003; Kugler and Saint-Paul, 2004; Bauer et al., 2007; Kugler and Pica, 2008; Bassanini and Garnero, 2013; Assunção et al., 2016). Such addition is important to be made due to, for instance, the key role institutions may play on explaining international differences in labor market flows (e.g., OECD, 2009; Bassanini, 2010). Yet, empirical evidence regarding the unemployment insurance effects on worker turnover is scarce in the literature, leaving aspects such as their magnitude with no perspective to economists.

Second, it develops a framework to study UI effects on unemployment inflow considering FSHC accumulation by the employees. The literature on UI effects is old and its core, rather, has been the effects regarding unemployment outflow (Topel and Welch, 1980; Atkinson and Micklewright, 1991; Karni, 1999). The influence on job search effort and on reservation wages are examples of what has long dominated the literature (Fredriksson and Holmlund, 2006; Tatsiramos and van Ours, 2014; Schmieder and von Wachter, 2016). More recently, though, some papers have contributed by enlightening the effects of UI on unemployment inflow (Wang and Williamson, 2002; Light and Omori, 2004; Zhang and Faig, 2012; Fuller et al., 2015; Zhang and Pan, 2017; Zweimüller, 2018), but, to my knowledge, FSHC accumulation has not been addressed yet.

The framework developed here consists of a labor market with search frictions, human capital accumulation and idiosyncratic labor disutility shocks that incorporate legislation details that determine eligibility for UI benefits. It is an adaptation of the basic job search model ${ }^{3}$ where an unemployed worker searches sequentially for a job subject to layoff risks and no information costs, but there is endogenous separation. In contrast to the basic model, the present framework has two features that change workers' incentive to quit over time. First, the eligibility to UI, that once attained, increases her reservation wage and makes her more inclined to resign from her job. Second, the idiosyncratic labor disutility shocks, that arrive at every period that she is employed and account for part of the job status changes and for the heterogeneity in the

\footnotetext{
${ }^{3}$ Terminology from the survey Rogerson et al., 2005. See McCall, 1970 for a seminal paper on sequential job search and Chade et al., 2017 for another survey on the subject.
} 
decisions by workers with same wage-tenure pairs.

To collect UI benefits, the worker must resign and resort to non-formal income for a living. That includes informality and self employment income, which are beyond the scope of this work to model. Though some usual labor market elements are set aside in this adaptation, such as total experience and participation decisions, we believe the nuances proposed to the basic model here have a primarily role in explaining the mechanism in this context.

For instance, one may be skeptical about the idea of a worker quitting her job to collect social benefits, but this is consistent with the existing evidence relating a spike in the unemployment inflow to the meeting of UI eligibility criteria, which involve working for a minimum period in most UI systems. ${ }^{4}$ Adding to the list of works that document increases in separation hazard due to UI eligibility, Christofides and McKenna, 1996 and Baker and Rea, 1998 study different changes in the minimum number of weeks worked required to collect UI benefits in Canada, the former in 1986-87 and the latter in 1990, and both conclude that separation is significantly more likely after UI eligibility is met. Also, papers like Fuller et al., 2015 and Doornik et al., 2018 regarding frauds in the UI system make more appealing the reading of these evidence as not a consequence solely of firms behavior. Further evidence on workers behavior responding to the incentives on UI system is provided in the next section by showing the relation of the hazard function to the replacement ratio.

In turn, albeit evidence on job tenure and wage growth is controversial, one can argue that the loss of FSHC accumulation may outweigh the forgo work experience involved in the quitting decision. That is because the former is completely lost in the labor market transition whereas the latter is transferable between firms. Yet, we recognize the importance total experience have to explain wages but once it can be viewed as a transferable asset between different firms its relevance to this decision exists only through the expected unemployment spell duration, which is exogenous in the proposed model.

Lastly, labor disutility shocks, though not much common in job search models, fit naturally in this context. First, because their incidence doesn't imply wage changes, which avoids further assumptions to keep wages monthly variations nearly steady and more close to what is observed in reality (BLS, 2018). Second, they are general enough to reflect the arrival of new job opportunities, which can be framed as a change in the worker perception about her current job due to the arrival of the new information resulting in a

${ }^{4}$ See Tatsiramos and van Ours, 2014 for a description of the structure of UI systems for different countries. 
separation just like in the real case of the arrival of an opportunity, alleviating the burden of not modelling them. In fact, these shocks can accrue from a variety of nonmonetary factors, such as sudden changes in the workplace, learning about it if there is asymmetric information in the recruiting process, and even from mood swings of the worker. ${ }^{5}$

We calibrate the model in subgroups defined by workers age and occupations skill group to reduce unmodeled heterogeneity. We approximate the occupation skill rank by the average wage of workers in the sample period. The calibration is conducted in two steps. First, statutory parameters and those with a direct counterpart in the data are calibrated. Then, a similar procedure to the Simulated Method of Moments is performed to recover the remaining structural parameters. We use two Brazilian data sets. The main one is a matched employer-employee data set that contains information on the universe of formal labor contracts. The second one is a survey on the Brazilian labor force. After calibration is finished, we run some counterfactual exercises.

In the first exercise, we evaluate the implications of rising the job tenure eligibility threshold to collect UI benefits. We find that, compared to the baseline, wages rise approximately 3.5\% (.035 log points), the average tenure grows $6,6 \%$ and the turnover rate rises 4.3 percentage points. We discuss the fact that both the average tenure and the turnover rate moved in the same direction and conclude that it depends on how the policy modifies the fraction of employed workers who voluntarily separate from their jobs.

In the second exercise, we exchange the baseline replacement rate schedule for flat schedules on two occasions. We assess the impact these changes have on the average job tenure of workers in selected wage ranges. All of them mapped into replacement rate ranges in the baseline. We find a negative relationship between the change in the UI replacement rate and the average employment duration.

The rest of this paper is organized as follows. Chapter 2 discusses the institutional background, presents the data and some stylized facts. Chapter 3 develops the model. Chapter 4 discusses the calibration method and show its results. Chapter 5 presents the counterfactual analysis and Chapter 6 concludes this work.

\footnotetext{
${ }^{5}$ See Rosen, 1986 for an exposition of a theory of equalizing differences and a discussion on nonmonetary advantages some positions might have. Examples of measurable job attributes with empirical appeal highlighted by the author include: "(1) onerous working conditions, such as risks to life and health, exposure to pollution, and so forth; (2) intercity and interregional wage differences associated with differences in climate, crime, pollution, and crowding; (3) special work-time scheduling and related requirements, including shift work, inflexible work schedules, and possible risks of layoff and subsequent unemployment; and (4) the composition of pay packages, including vacations, pensions, and other fringe benefits as substitutes for direct cash wage payments".
} 


\section{2 \\ Institutional Background, Data and Stylized Facts}

This chapter provides the relevant institutional information for the empirical analysis conducted in this paper, presents the data used for it and comment on the stylized facts in the formal sector in Brazil related to it.

\section{1}

\section{Institutional background}

During the period analyzed, from 2007 to 2010, a formal worker in Brazil was eligible to UI if terminated without cause ${ }^{1}$ after 6 months of job tenure and if it has been 16 months since the dismissal date of her last successful application for the program. The potential benefit duration varied accordingly to her total months employed in the formal sector in the past 36 months prior to the layoff. It equaled 3, 4 or 5 monthly payments, depending if she was formally employed, respectively, for 6 to 11, 12 to 23 or 24 to 36 months total in the past 36 months prior to the layoff. The benefit level was settled based on her average wage in the last 3 months prior to the dismissal. Its design resulted in the following replacement rate schedule as a function of the average salary range: from 1 to 1.25 minimum wages, the replacement rate decreased from $100 \%$ to $80 \%$; from 1.25 to 1.65 , it was exactly $80 \%$; from 1.65 to 2.75 , it decreased from $80 \%$ to $50 \%$; and, above 2.75 , it decreased starting from $50 \%$. Finally, the UI program was funded by taxes (PIS and COFINS) on firms' net profits or sales depending on the industry in which they operated.

A few comments about the design of the Brazilian UI program are worthwhile. First, replacement rates are high at the bottom of the wage distribution. This feature of the Brazilian UI program partly motivates the main mechanism exploited in this paper that is associated to the rise in the unemployment inflow around the UI eligibility threshold: the increase in the worker's reservation wage. Stylized facts consistent to the functioning of this mechanism are presented in the next subsection which, along with the fact that $41.77 \%$ of the workforce in the sample earn wages in the high replacement rate

\footnotetext{
${ }^{1}$ For further details, see the Article 482 of the Consolidação das Leis de Trabalho (CLT) enacted in 1943, which along with the 1988 Federal constitution, regulates formal labor contracts in Brazil.
} 
range (i.e., [100\%-80\%]), suggest its relevance to the worker turnover in the economy.

Second, the funding system of the Brazilian UI program imposes no direct costs to firms as a function of their layoff policy. Because there is no experience rating in the Brazilian UI program, firms' layoff histories are not related to the taxes they pay to fund it. By the time an employee becomes eligible for UI benefits, no other labor market institution justifies a response from the employer. ${ }^{2}$. Therefore, the eligibility of a worker should have no primary role in the firms' separation decision ${ }^{3}$, unlike the employees' case. Thus, the worker side should have a primary role in the rise of the unemployment inflow around the eligibility threshold. ${ }^{4}$.

Third, termination without cause is not a fully enforced requirement in Brazilian labor market programs ${ }^{5}$. In fact, firms and workers often simulate layoffs when the worker actually wanted to quit ${ }^{6}$. Such behavior justifies an increase in the value of quitting after eligibility to UI has been met, despite the termination requirements, and is consistent with some of the patterns observed in the data, including the accurate timing of layoff around the eligibility threshold as shown in the next subsection ${ }^{7}$.

These simulations, known as fake layoff agreements, exist in the economy as a result of the labor market institutions design and outweigh shirking as a successful exit strategy from employment relations ${ }^{8}$. They have been extensively studied in Brazil ${ }^{9}$ and are possibly not exclusively relevant to the

${ }^{2}$ See Assunção et al., 2016 for an exposition of the labor market institutional setting in Brazil in the period studied here.

${ }^{3}$ Assunção et al., 2016 studies the institutional incentives in Brazil on the firm side and claims that firms may delay layoffs to share the rents over the social benefits involved in the dismissal or due to fairness considerations. We claim that although, this could be the case, it may not be the may driving force behind the evidence. First, because the sharing of these benefits involve an informal agreement with a potentially dissatisfied part which will have all the bargaining power once the agreement starts, the employer-initiated negotiation may not even exist in equilibrium. Second, the fairness considerations depend on preferences, which should average out in a large economy.

${ }^{4}$ We recognize that the UI incentives to separation must affect firms' hire policies too. This way, results regarding changes in that institution, should be viewed as a bound to the real response where firms would response with their hiring policy as well.

${ }^{5}$ de Barros et al., 2001 finds that around two-thirds of the formal workers who have quit their jobs had access to the severance account, FGTS, in spite of the requirement of termination without cause, using PNAD 1990 and PME 1998.

${ }^{6} \mathrm{CNI}, 2016$ reveals that $54 \%$ of the workers who had more than one job (formal or informal) claim that they had left their last one voluntarily, mostly by quitting (28\%) or asking to be fired (15\%)

${ }^{7}$ Doornik et al., 2018 studies the layoffs around the UI eligibility threshold in Brazil and finds a firing and rehiring pattern consistent to worker and firm colluding to time formal unemployment to UI eligibility.

${ }^{8}$ From the same sample aforementioned, CNI, 2016 finds that only $2 \%$ of the workers ended their job relations by forcing their layoff.

${ }^{9}$ See section 2.3 in Assunção et al., 2016 for a review of these studies. 
local labor market (e.g., Fuller et al., 2015 calculates that quits represented $13.9 \%$ of fraud overpayments in the United States UI system in 2007).

Fake layoff agreements can be framed as the following. An eligible to UI worker who wishes to separate but still have access to her layoff benefits ${ }^{10}$ signals this desire to her employer which, after receiving this message, decides between fighting or colluding accordingly to the firm own policy. Fighting can be a viable option since termination without cause is costly to the employer ${ }^{11}$ and the benefits of an agreement are uncertain ${ }^{12}$, but also involves keeping a poorly performance worker employed until its resolution plus face the prospect of losing and having to pay for a real layoff without the potential benefits of the agreement. Collusion may be chosen because it can be a cheaper alternative than fighting to separate from a worker whose productivity is expected to drop over the next periods following the signal, but again, there is no guarantee of compliance by the worker.

As the evidence mentioned in Chapter 1 reveals, collusion does exist in equilibrium. Its realization, however, depends on some unobserved factors to the economist, such as firms policies regarding fake layoff agreements, workers propensities to engage in this sort of fraud and the probability of compliance attributed by the employer to the worker. Although we believe that workers have some information about employers' policies toward these agreements and only signal their desire to make deals when they believe to have good chances to succeed, we choose to simplify this framework by assuming they are subjected

${ }^{10}$ Layoff benefits include access to one's seniority account, FGTS, which would have been otherwise only granted upon retirement or in some very exceptional cases (e.g., terminal diseases or buying own house). This account is funded by monthly deposits of $8.5 \%$ of the worker's wage by the employer, it is managed by a state bank and it yields a $3 \%$ annual interest rate plus compensation for inflation, given by the TR interest rate, that barely accounts for the actual inflation. Due to its low return and the termination requirement to access its balance, the FGTS system was object of study regarding its effects on labor turnover (see Gonzaga et al., 2003 and the discussion in section 2.3 in Assunção et al., 2016).

${ }^{11}$ In Brazil, legislation grants a probation period free of firing costs during the first 3 months of the employment relations. Hence, by the time eligibility to UI is met, which occurs at the 6th month of job tenure, the probationary period has already expired and a termination without cause incurs firing costs settled by the labor market regulation. In the period 2007-2010, they included a one-month advance notice (typically one monthly wage), $40 \%$ of the amount deposited in the seniority account while on the current job paid to the worker and $10 \%$ of the same amount paid to the government. Anecdotal evidence suggests that the worker funds the firm this $10 \%$ fine and pays back the $40 \%$ one. But they are inconclusive about the agreement on the advance notice. We believe the worker keeps that part, once the employer would probably have to pay next period's wage anyway if she chooses to fight.

${ }^{12}$ Fake layoff agreements were informal and illegal in the 2007-2010 period, so, naturally, they were not fully enforceable. 
to a given probability of reaching an agreement once they decided to quit ${ }^{1314}$. This way, we lose reality on the setup of the fake layoff agreements but are still able to consider their consequences to the economy without the use of additional state variables.

\section{2 \\ Data}

We use two data sets to perform the empirical analysis. The main data source is the Registro Anual de Informações Sociais (RAIS), an administrative database collected by the Ministry of Labor that contains information on the universe of formal labor contracts. It is a matched employer-employee data set containing the information reported annually by the tax-registered firms to the Ministry of Labor regarding all formal workers they had in the previous year. It has data on job tenure, age, education, sector, wage in December, last wage received, contractual wage, average wage, hiring and separation dates. Thus, it is ideal for duration analysis on formal employment relations. We only use data from 2007 to 2010 for all data sets.

We also use the survey Pesquisa Mensal do Emprego (PME) conducted by the Instituto Brasileiro de Geografia e Estatistica (IBGE), that interviews households for a period of four consecutive months, then for another period of the same duration eight months later. It gathers information from workers in all labor market states (i.e., including what we call formal unemployment which consists of informality, self-employment, and unemployment) and has a panel structure, although it is representative only for the six largest metropolitan areas of Brazil. This data set allows us to calculate transitions in the labor market. It is especially useful because it records fake layoff agreements as a voluntary separation. Although this information is self-reported, PME is still more informative than the RAIS which is an administrative data set and does not consider that option.

${ }^{13}$ Next subsection shows that there is no rise in the quits hazard rate function around the eligibility to UI threshold suggesting quits regardless of the negotiation result. Still, if only a fraction of the employed workers are subjected to a satisfactory degree of certainty over reaching an agreement in the economy, one should expect the simplified setup to have similar aggregate consequences in the economy as the full setup.

${ }^{14} \mathrm{We}$ assume that workers quit regardless of the resolution of the agreement. We could allow them not to do that, but it wouldn't make much difference in the aggregate, as still, a share of the workers would be reaching an agreement. Also, it would not add reality to the set up of the agreements, if one believes that workers anticipate the resolution of the agreement even before proposing to quit rather than observing its outcome, as we have pointed out. 


\section{3}

\section{Stylized Facts}

In the following, we present some stylized facts regarding the UI effect on formal employment in Brazil in the 2007-2010 period. We use the RAIS data set to derive them and, henceforth, we refer to the [100-80], (80-50] and (50-0] replacement rate ranges as high, medium and low replacement rates.

First, Figure 2.1 reveals that the wage distribution in Brazil was heavily concentrated at the bottom. In fact, almost $50 \%$ of the employees did not earn more than $65 \%$ higher than the minimum wage in the $2007-2010$ period, as the share of workers with high replacement rate in Figure 2.2 suggests. Roughly $90 \%$ of the formal labor force was subject to at least $50 \%$ of replacement rate by the Brazilian UI program in that same period. Moreover, close to $50 \%$ of the formal employees had at least $80 \%$ of replacement rate provided by the UI program. That is, the share of formal employees in Brazil subjected to generous replacement rate was expressive, what suggests a non-negligible effect of the UI incentives in the economy.

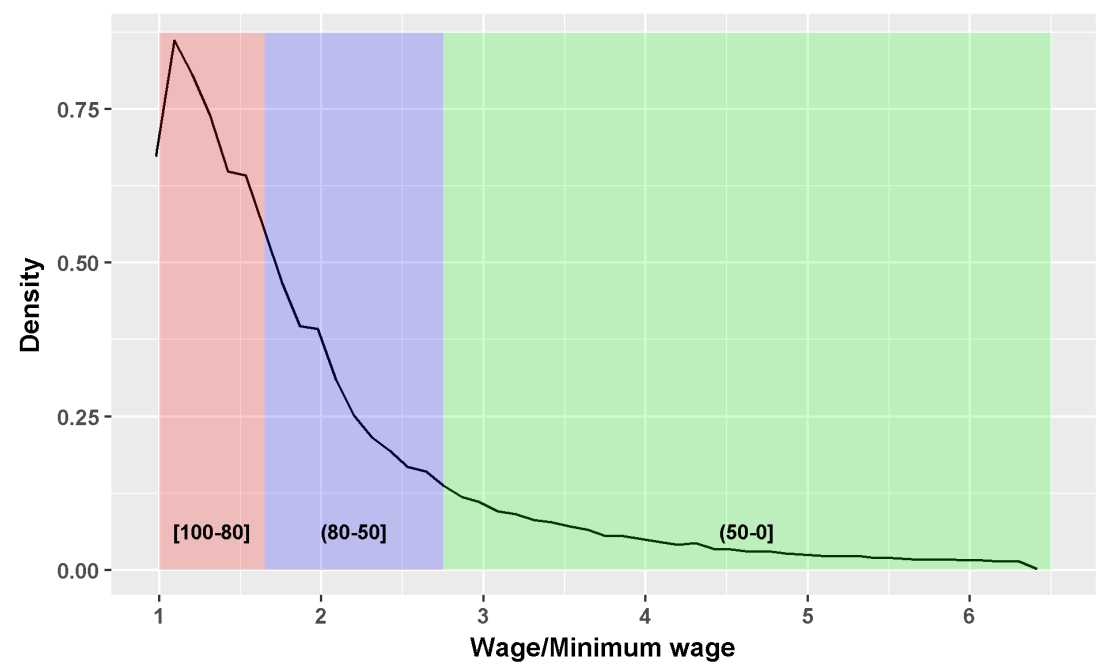

Figure 2.1: Kernel density estimation of wage/minimum wage distribution of formal employees in Brazil. RAIS, 2007-2010. Kernel function = Gaussian, bandwidth $=.02$.

Second, Figure 2.3 reveals jumps in the separation hazard function for the first year of the employment relation. The first one, occurring at the third month, is not object of our study. It exists due to a discontinuity in the firing costs for dismissals without cause - the end of the 90-days probation period. Therefore, it concerns solely the firms' behavior in response to the labor market institutions, which is out of the scope of this paper and is the object of study in Assunção et al., 2016. Finally, there is a discontinuity in the separation hazard in the sixth month of the employment relationship. That illustrates the findings 


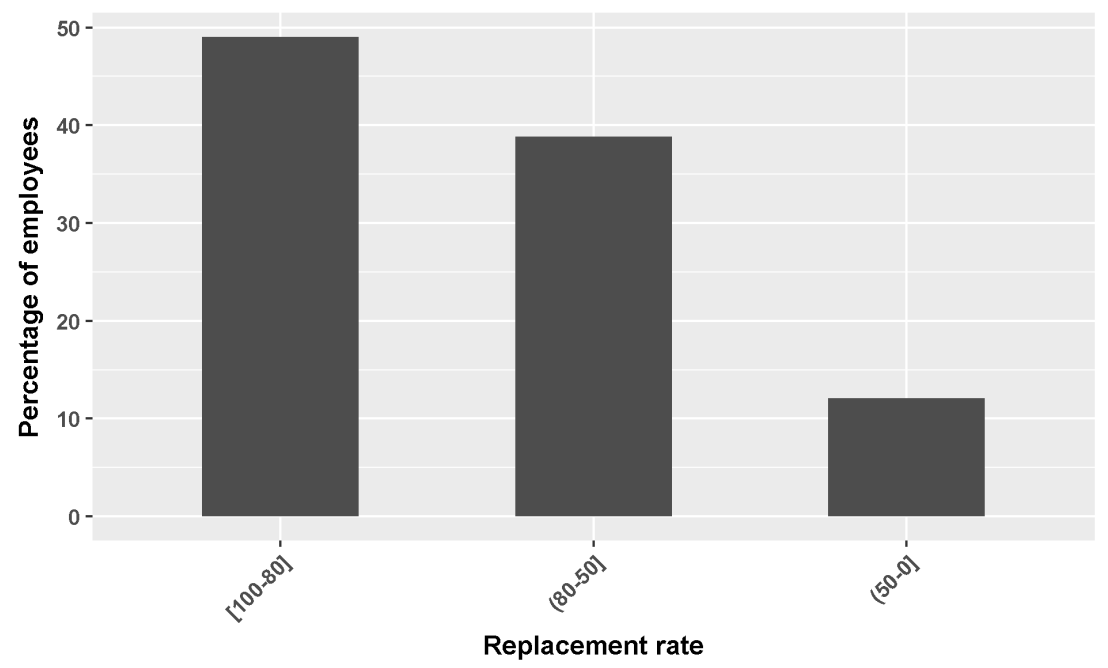

Figure 2.2: Replacement rate distribution of formal employees in Brazil. RAIS, 2007-2010.

previously mentioned ${ }^{15}$ that establish causality of the UI eligibility in the rise of the unemployment inflow around the eligibility threshold.

Figure 2.4 shows that in fact, the increase in the separation hazard at the UI eligibility threshold is due to the rise in the likelihood of a termination without cause, which is another requirement for the collection of UI benefits. As opposed to the jump in the 3rd month of employment, there is no discontinuity in the firing costs structure that justifies a direct response of the firms to explain the observed pattern. Plus, considering that fake layoff agreements make possible for workers eligible to UI benefits quit and still collect these benefits, it is reasonable to focus on their behavior to study the UI effect on the economy.

Finally, Figure 2.5 shows that the intensity of the effect of the UI eligibility varies positively with the relative magnitude of the benefits granted. That can be seen by the heterogeneity of the rise in the unemployment inflow around the UI eligibility threshold with respect to the replacement rate, as captured by the difference between the 4th and the 6th-month hazard rate of the employment relationship. Hence, workers granted high replacement rates are the most intensively affected by the UI eligibility. This paper is the first one, to the best of our knowledge, to document this specific pattern, which is another evidence that the UI program affects the employment relationships.

\footnotetext{
${ }^{15}$ Carvalho et al., 2018 and Doornik et al., 2018.
} 


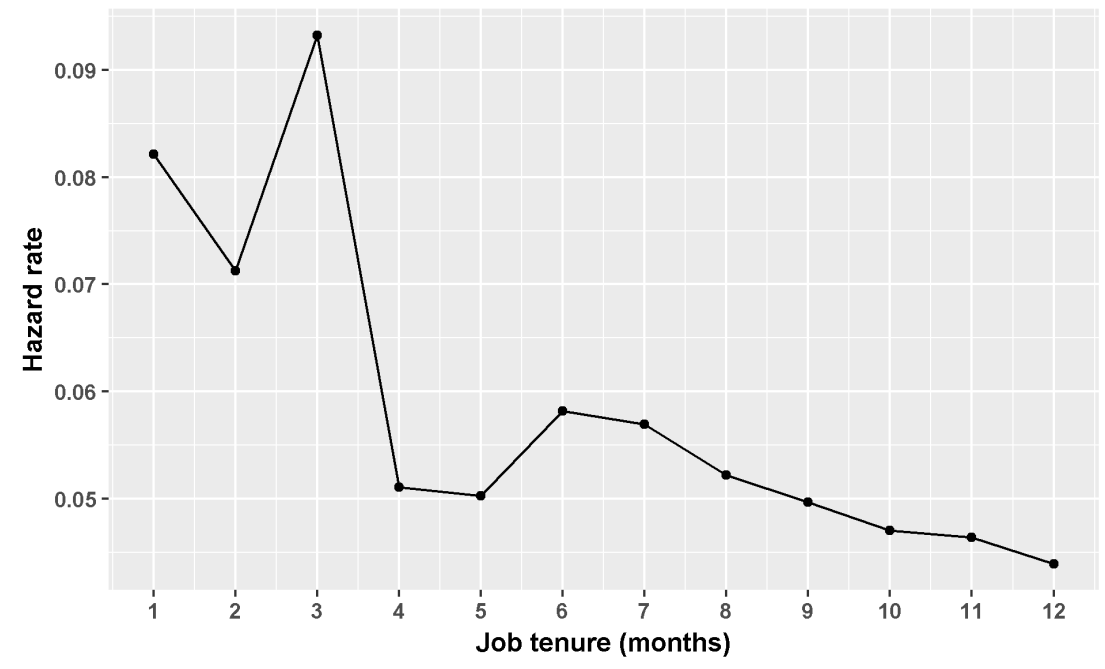

Figure 2.3: Aggregate Separation hazard rate by job tenure of formal employees in Brazil. RAIS, 2007-2010.

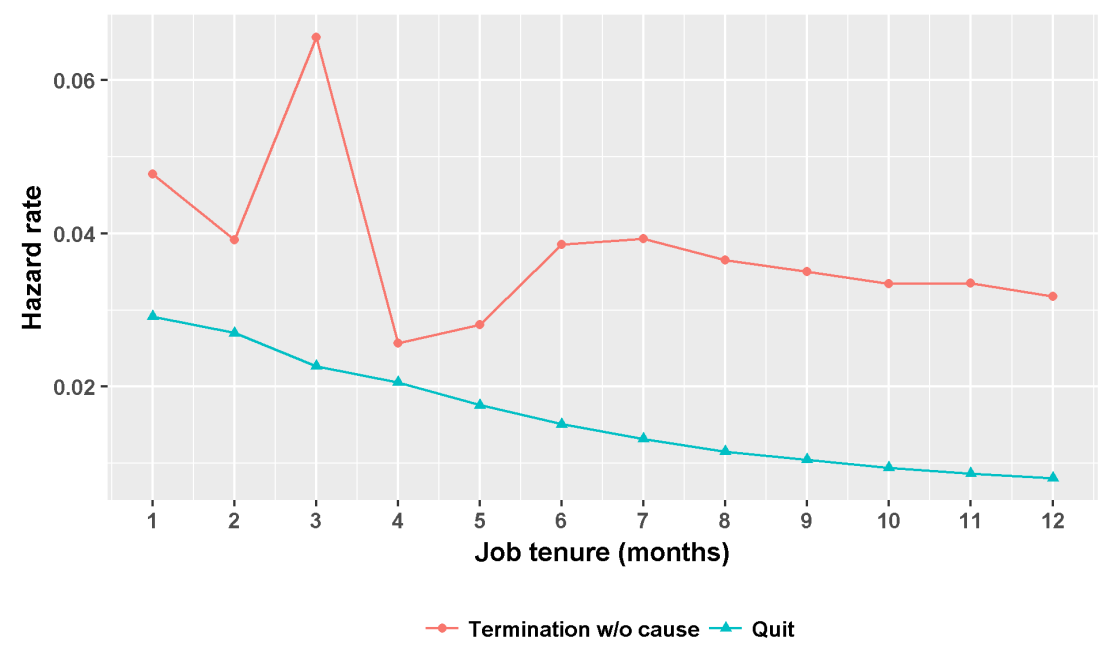

Figure 2.4: Separation hazard rate by reason of separation by job tenure of formal employees in Brazil. RAIS, 2007-2010. 


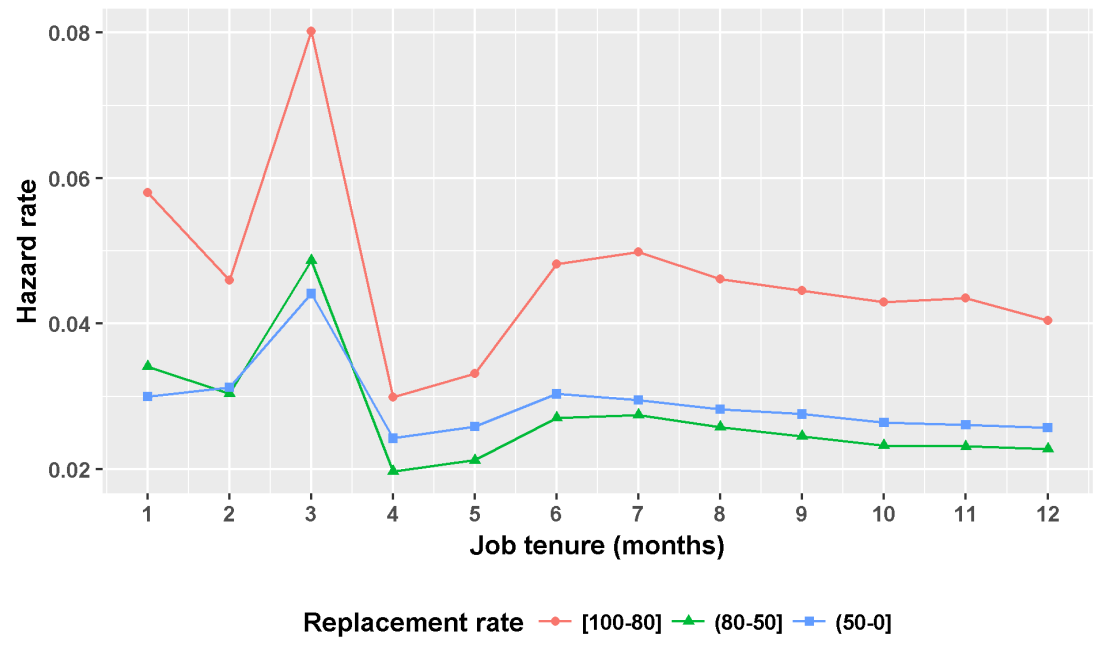

Figure 2.5: Termination without cause hazard rate by replacement rate by job tenure of formal employees in Brazil. RAIS, 2007-2010. 


\section{3}

\section{The model}

This chapter develops a model where employed workers gain eligibility to UI benefits through work and can collect them even when they quit their jobs provided they reach an informal agreement with their employers to fake a layoff. It is a partial equilibrium model based on the basic job search framework in discrete time ${ }^{1}$, where workers are allowed to quit. While in the traditional model an employee would never want to, in the present context she might do it due to the possibility of reaching a fake layoff agreement with her employer and gain access to the benefits from the UI program. These agreements make the value of the quit option respond to UI eligibility even when being laid off is a requirement, but they are uncertain to reach and costly when compared to truly being laid off. Hence, a worker's decision to try to extract rents from the UI system is not innocuous.

We consider a labor market with search frictions, eligibility criteria to UI, human capital accumulation, idiosyncratic labor disutility shocks and fake layoff agreements where there is a unitary mass of homogeneous workers that can either be employed or unemployed and take the market conditions as given.

\section{1 \\ Timing of events}

Let $t$ be the time a worker has spent working continuously on the same job. We will refer to it as her job tenure. A job at a firm pays wage $_{t}=w+g(t)$ and gives her an utility stream of $w+g(t)+\varepsilon$, where $w$ is the initial wage offer, $g(t)$ is a deterministic trend reflecting human capital accumulation on that specific job and $\varepsilon$ is a worker specific zero mean shock. ${ }^{2}$ We assume this shock to be independently and identically distributed (i.i.d.) accordingly to a known distribution $F_{\varepsilon}(\varepsilon)$.

At the beginning of the period, the idiosyncratic shock $\varepsilon$ is revealed to the workers. Employed workers decide whether they stay employed and earn their

\footnotetext{
${ }^{1}$ See Rogerson et al., 2005 for a survey on search models to the labor market.

${ }^{2}$ Bagger et al., 2014 see it reflecting stochastic changes in the individual's productivity that may come from preference or technological shocks. In our context we can't give the latter interpretation because $\varepsilon$ is not reflecting in the worker's productivity. Thus, it is a purely preference shock.
} 
current wages or quit their jobs, what allows them to receive non-formal income $b$ and, with probability $\varphi$, reach a fake layoff agreement with their employers, providing them access to the UI benefits $\mathrm{UI}(w, t)^{3}$. A worker becomes eligible to collect UI benefits once she completes 6 periods in the same job. ${ }^{4}$ The amount she is entitled to is a function of the wage she earns and her job tenure in this job from which she is separating ${ }^{5}$. So, a worker who quits remains with her current job tenure and wage for that period, variables that now have the interpretation of last job characteristics ${ }^{6}$.

By the end of the period, any employed worker sees her match got broken with probability $\delta$ or keeps her job with probability $1-\delta$. In the former case, she starts the next period unemployed whereas, in the latter, her job tenure raises by one unit. When unemployed, a worker finds a new match with probability $\alpha$ to start working in the next period and, if she does so, draws an i.i.d. wage offer from a continuous known sampling density $f_{w}(\cdot)=F_{w}^{\prime}(\cdot)$, with support $\left[w_{\text {min }}, \infty\right)^{7}$.

\section{2}

\section{Fake layoff agreements}

Actual layoffs incur in the following firing costs to the firms provided they occur after the 90-days probation period at the beginning of the employment relationships: a one-month advance notice $a n\left(w, t ; \tau_{a n}\right)$, a firing fine paid to the worker as a share $\psi_{w}$ of the balance of her seniority account accumulated while working in her current job, $\operatorname{FGTS}\left(w, t ; \tau_{\mathrm{FGTS}}, r_{\mathrm{FGTS}}\right)$, plus, a firing fine paid to the government $\psi_{g}$ as a share of that same amount. In a fake layoff agreement, the worker asks her employer to officially fire her and promises to return the share $\psi_{w}$ of the accumulated balance in her seniority account paid

${ }^{3} \mathrm{UI}$ is not the only benefit granted by the labor market regulation upon layoff that we include in the model. Others are the FGTS, advance notice, and the firing fines, all mentioned in Section 2.1. Notwithstanding, UI is the primary benefit associated with the patterns observed in the data, so we make reference in the text only to UI while other benefits are implied.

${ }^{4}$ The Brazilian law requires at least 6 months tenure on the same job to collect the unemployment insurance, what our model will capture, and 16 months since the last layoff that generated a collection of the benefit. This waiting period condition we do not model, rather we assume that every worker in our sample is a formal employee who has never collected unemployment insurance before.

${ }^{5}$ Our model does another simplification with respect to the law. The legislation states that the number of payments depends on the total period working in the last 36 months. We do not add this complication to the model what avoids the introduction of another state variable.

${ }^{6} \mathrm{So}$, if the worker is unemployed and her state variables are non-null one should read them as last job information.

${ }^{7}$ By construction, refuse a job offer to remain unemployed and accept it, but quitting tomorrow is the same thing in our model, once $\varepsilon$ is drawn in every state. 
by the firm and fund the share $\psi_{g}$ of that same amount that the firm must pay to the government. We assume she keeps the advance notice.

Define $\Lambda=\left\{\tau_{a n}, \tau_{\mathrm{FGTS}}, r_{\mathrm{FGTS}}, \psi_{w}, \psi_{g}\right\}$, and call it the statutory parameters vector. The benefits received by a worker, with initial wage offer $w$ and $t$ months of job tenure, when she is laid off, $\mathrm{I}_{\mathrm{L}}(w, t ; \Lambda)$, is

$$
\begin{aligned}
& \mathrm{I}_{\mathrm{L}}(w, t ; \Lambda)=\operatorname{FGTS}\left(w, t ; \tau_{\mathrm{FGTS}}, r_{\mathrm{FGTS}}\right)+\mathrm{UI}(w, t ; \beta)+ \\
& +\mathrm{I}_{t>3}\left\{a n\left(w, t ; \tau_{a n}\right)+\psi_{w} \times \operatorname{FGTS}\left(w, t ; \tau_{\mathrm{FGTS}}, r_{\mathrm{FGTS}}\right)\right\},
\end{aligned}
$$

where $\operatorname{FGTS}\left(w, t ; \tau_{\mathrm{FGTS}}, r_{\mathrm{FGTS}}\right)$ is the severance balance account accumulated in the job, an $\left(w, t ; \tau_{a n}\right)$ is a one-month advance notice and $\psi_{w} \times$ $\operatorname{FGTS}\left(w, t ; \tau_{\mathrm{FGTS}}, r_{\mathrm{FGTS}}\right)$ is the fine the employers must pay to their workers together with the advance notice as a firing fine if the lay off occurs after the 90-days probation period, hence the indicator for 3 or more periods of job tenure. $\mathrm{UI}(w, t ; \beta)$ is the unemployment insurance benefit and $\beta$ is the discount factor ${ }^{8}$.

She proposes to payback the $\psi_{w} \times \operatorname{FGTS}\left(w, t ; \tau_{\mathrm{FGTS}}, r_{\mathrm{FGTS}}\right)$ firing fine paid to her and fund the $\psi_{g} \times \operatorname{FGTS}\left(w, t ; \tau_{\mathrm{FGTS}}, r_{\mathrm{FGTS}}\right)$ that her employer must pay to the government due to the layoff. Hence, the benefits of a successful agreement to an employee with initial wage offer $w$ and $t$ months of job tenure, $\mathrm{I}_{\mathrm{A}}(w, t ; \Lambda)$, is given by:

$$
\begin{aligned}
& \mathrm{I}_{\mathrm{A}}(w, t ; \Lambda)=\operatorname{FGTS}\left(w, t ; \tau_{\mathrm{FGTS}}, r_{\mathrm{FGTS}}\right)+\mathrm{UI}(w, t ; \beta)+ \\
& +\mathrm{I}_{t>3}\left\{a n\left(w, t ; \tau_{a n}\right)-\psi_{g} \times \operatorname{FGTS}\left(w, t ; \tau_{\mathrm{FGTS}}, r_{\mathrm{FGTS}}\right)\right\},
\end{aligned}
$$

In our framework, a worker with initial wage offer $w$ and $t$ months of job tenure, decided to quit, is allowed to propose a fake layoff agreement to her employer in order to collect the institutional benefits resulted from it, $\mathrm{I}_{\mathrm{A}}(w, t ; \Lambda)$. She succeeds with probability $\varphi$ but is not allowed to turn back in her decision to separate. That is, she separates regardless of the negotiation outcome. Importantly, given that she has decided to quit, she will always choose to propose an agreement as its payoff is equal to the payoff of not proposing one plus the expected return of collecting its benefits, which is always positive.

\footnotetext{
${ }^{8}$ We assume that UI benefits are paid upfront, despite of the monthly payments system in reality. This assumption avoids the use of an additional state variable and might not be too strong since Gerard and Gonzaga, 2016 finds that $67 \%$ of the dismissed workers entitled to the maximum number of monthly payments of the UI program (i.e., five) exhaust their benefits in Brazil.
} 


\section{3 \\ Bellman Equations}

\subsection{1}

\section{Unemployment value function}

Let $\mathrm{U}$ be the value of formal unemployment. One can write:

$$
\mathrm{U}=b+\beta \mathrm{E}_{\tilde{\varepsilon}}\left[\alpha \mathrm{E}_{\tilde{w}}[\max \{\mathrm{V}(\tilde{w}, 0, \tilde{\varepsilon} ; \Lambda), \mathrm{U}\}]+(1-\alpha) \mathrm{U}\right] .
$$

where $\beta$ is the discount factor and $\mathrm{E}_{x}$ is the expectation operator with respect to the variable $x$.

The worker's unemployment value is given by the current-period utility flow plus next-period continuation value, discounted with factor $\beta$. The current-period utility flow consists of the non-formal earnings stream $b$. The continuation value has two components: with probability $\alpha$, the unemployed worker gets a job offer drawn from the wage distribution $F_{w}$; with probability $1-\alpha$, he does not get an offer and starts the next period unemployed.

\subsection{2}

\section{Layoff value function}

Let $\mathrm{L}(w, t ; \Lambda)$ be the value of being laid off for a worker with initial job offer $w$ and $t$ months of job tenure. One can write:

$$
\mathrm{L}(w, t ; \Lambda)=\mathrm{U}+\mathrm{I}_{\mathrm{L}}(w, t ; \Lambda),
$$

where $U$ is the value of unemployment and $\mathrm{I}_{\mathrm{L}}$ is a function with the layoff benefits granted by the labor market regulation, which includes access to the severance account, $\operatorname{FGTS}\left(w, t ; \tau_{\mathrm{FGTS}}, r_{\mathrm{FGTS}}\right)$, UI benefits, $\mathrm{UI}(w, t ; \beta)$, and the firing fine paid to the employee if dismissed after the 90-days probationary period, that consists of one-month advance notice, an $\left(w, t ; \tau_{a n}\right)$, plus $\psi_{w} \times$ $\operatorname{FGTS}\left(w, t ; \tau_{\mathrm{FGTS}}, r_{\mathrm{FGTS}}\right)$.

\subsection{3}

\section{Agreement value function}

Let $\mathrm{A}(w, t)$ be the value of making a fake layoff agreement for a worker with initial job offer $w$ and $t$ months of job tenure. One can write:

$$
\mathrm{A}(w, t ; \Lambda)=\mathrm{U}+\mathrm{I}_{\mathrm{A}}(w, t ; \Lambda),
$$

where $\mathrm{U}$ is the value of unemployment and $I_{A}$ are the institutional benefits resulted from the fake layoff agreement to the worker. We assume that these agreements consist of the worker funding the $\psi_{g} \times \operatorname{FGTS}\left(w, t ; \tau_{\mathrm{FGTS}}, r_{\mathrm{FGTS}}\right)$ 
fee that the employer needs to pay to the government and returning the $\psi_{w} \times \operatorname{FGTS}\left(w, t ; \tau_{\mathrm{FGTS}}, r_{\mathrm{FGTS}}\right)$ firing fine her employer needed to pay her to dismiss her.

Therefore, the value of quitting to an employed worker with initial job offer $w$ and $t$ months of job tenure, $\mathrm{Q}(w, t ; \Lambda)$, can be written as:

$$
\mathrm{Q}(w, t ; \Lambda)=\varphi \mathrm{A}(w, t ; \Lambda)+(1-\varphi) \mathrm{U}=\mathrm{U}+\varphi \mathrm{I}_{\mathrm{A}}(w, t ; \Lambda),
$$

where $\varphi$ is the probability of a successful fake layoff agreement occur.

The worker who quits her job separates from it regardless of the negotiation outcome, which succeeds with probability $\varphi$ and fails with probability $1-\varphi$. Hence, the worker's quitting value is given by two components: the value of formal unemployment, with certainty; plus, with probability $\varphi$, her share of the institutional benefits resulted from the fake layoff agreement.

\subsection{4}

\section{Employment value function}

Let $\mathrm{V}(\mathrm{w}, \mathrm{t}, \varepsilon)$ be the value of employment for a worker with initial wage offer $w$, at job tenure $t$ and the productivity shock $\varepsilon$. Thus,

$$
\begin{aligned}
& \mathrm{V}(w, t, \varepsilon ; \Lambda)=w+g(t)+\varepsilon+ \\
& +\beta \mathrm{E}_{\tilde{\varepsilon}}[(1-\delta) \max \{\mathrm{V}(w, t+1, \tilde{\varepsilon}), \mathrm{Q}(w, t+1 ; \Lambda)\}+ \\
& +\delta \mathrm{L}(w, t ; \Lambda)]
\end{aligned}
$$

The worker's employment value is given by the current-period utility flow $w+g(t)+\varepsilon$ and next-period continuation value discounted by the factor $\beta$. The continuation value consists of two components: with probability $\delta$ the worker sees her match broken and enters unemployment with her previous job information (i.e., wage $w$ and tenure $t$ ); with probability $1-\delta$, the job match survives to the next period, when she will be able to choose whether to stay employed or quit her job.

Thus, every period, employed workers choose their employment status (i.e. employment or unemployment) such that:

$$
\mathrm{W}(w, t, \varepsilon ; \Lambda)=\max _{\{\mathrm{emp}, \mathrm{unemp}\}}\{\mathrm{V}(w, t, \varepsilon ; \Lambda), \mathrm{Q}(w, t ; \Lambda)\},
$$

where $\mathrm{W}(w, t, \varepsilon ; \Lambda)$ is the value of their choice. 


\section{Calibration}

This chapter describes the calibration of the model developed in Chapter 3. Such a procedure is sufficient to obtain all objects regarded there and will allow us to perform counterfactual exercises. It is conducted in a twostep set. First, we calibrate the statutory parameters and those with a direct counterpart in the data we have available. Then, we calibrate the remaining parameters by generating simulated data, computing a few selected moments and minimizing their distance from real data counterparts.

We calibrate the model in subgroups defined by workers age and occupations skill. Age groups are defined as 18-25, 26-35 and 36-49. Evidence reveals that there is substantial heterogeneity in labor market turnover rates by age (see Corseuil et al., 2014). Skill groups are defined as Q1, Q2, Q3, and Q4, which are the quartiles of an occupational skill rank we built approximating the skill rank of an occupation by its average wage in 2007-2010. In Brazil, occupations are classified by the Classificação Brasileira de Ocupações (CBO) 2002 and there is empirical evidence revealing heterogeneity in the returns of the human capital accumulation depending on the type of job performed by workers (see Gonzaga and Guanziroli, 2017). This is particularly important to account for because human capital accumulation affects both the current and the continuation value of employment, as implied by Equation 3-7.

\section{1}

\section{Parameterization}

We assume the initial wage offer distribution, $F_{w}(w)$, to be a truncated normal distribution $\mathrm{N}\left(\bar{w}, \sigma_{w}^{2}\right)$ where $w \in\left[w_{\text {min }},+\infty\right)$. The wage growth function, $g(t)$, is $\sum_{i=1}^{3} \gamma_{i} \times d_{i}$, where $d_{i}$ is an indicator of $i$ years completed at the same job. The preference shock distribution, $F_{\varepsilon}(\varepsilon)$, is assumed to be normally distributed as $\mathrm{N}\left(0, \sigma_{\varepsilon}^{2}\right)$. The unemployment insurance benefits $\mathrm{UI}(w, t ; \beta)$ follows the description in Section 2.1. The severance account balance, $\operatorname{FGTS}\left(w, t ; \tau_{\mathrm{FGTS}}, r_{\mathrm{FGTS}}\right)$ is based on the Brazilian labor regulation, and is equal to $\log \left(\sum_{j=0}^{t-1} \exp \left\{\right.\right.$ wage $\left.\left._{j}\right\} \times \tau_{F G T S} \times\left(1+r_{F G T S}\right)^{t-j}\right)$ for $t>0$ and 0 
otherwise, where wage $_{j}$ is defined on Chapter $3^{1}$. Finally, the advance notice, $a n\left(w, t ; \tau_{a n}\right)$ is taken to be $\tau_{a n} \times w a g e_{t}$.

\section{2}

\section{Calibration Method}

Given the model specifications and the chosen parameterizations, we define the vector of parameters as $\Xi=\{\Omega, \beta, \Delta, \Lambda\}$, further specified below, and proceed with the calibration. Although we perform it by age-skill cells, some of the parameters do not vary. The only ones in this case are $\beta, w_{\text {min }}$ and those in $\Lambda$. Once that is noted, we suppress the cell index throughout the calibration discussion.

In the first step of the calibration, $\beta, \Delta$ and $\Lambda$ are calibrated. $\beta$ is based on the real interest rate for the Brazilian economy in Narita, 2017, which is equal to $0.5 \%$ per month. It is calculated as $(1 /(1+.005))$ and is approximately equal to .995 .

$\Delta$ is the vector of parameters directly observed in the data and it is defined as $\Delta=\left\{\alpha, \delta, \gamma_{1}, \gamma_{2}, \gamma_{3}, \bar{w}, \sigma_{w}, w_{\text {min }}\right\}$. Details on the calibration are in the Appendix B. The transition parameters, $\alpha$ and $\delta$, are calculated according to labor market transitions into and out-from the formal sector constructed using the PME. Due to data limitation, these parameters only vary by workers age. We have 206,531 observations for workers 18-25 years old, 249,441 for 26-35 years old and 308,329 for 36-49 years old in PME. The wage growth parameters, $\gamma_{1}, \gamma_{2}, \gamma_{3}$, are obtained from Mincer equations estimated using RAIS. The number of observations in each cell lies between 4,893,238 - 13,192,912 in RAIS. The parameters of the initial wage offer distribution, $\bar{w}, \sigma_{w}, w_{m i n}$, are calibrated according to their direct analogs from the distribution of the log of the contractual wage observed in each cell in RAIS. An underlying hypothesis in this procedure is that the acceptance rate of formal job offers by workers in formal unemployment is close to one. This is an extrapolation of the assumption made in Bagger et al., 2014 that on that occasion was based on the findings of van den Berg, 1990 regarding unemployed workers, but in this case is not limited to these as it includes self-employed and informal workers too. The minimum wage is $w_{\text {min }}=6.046072$, which is the log of the minimum contractual wage in the distribution in 2010 Brazilian Reais.

Concluding the first step of the calibration, $\Lambda$ is the vector of statutory parameters defined in Section 3.2. Its parameters are calibrated accordingly

\footnotetext{
${ }^{1}$ The FGTS depends on the employer wage history. Because in the present context the wage evolution is deterministic, one can recover it only by using the initial wage offer $w$ and her current job tenure $t$.
} 
with the Brazilian Labor regulation that establishes them the following values: $\tau_{a n}=1, \psi_{w}=.4, \psi_{g}=.1, \tau_{F G T S}=.085$ and $r_{F G T S}=-0.0820935 \%{ }^{2}$.

In the second step, the parameters calibrated before are taken as given and the remaining ones are calibrated. $\Omega$ is defined as

$$
\Omega=\left\{b, \sigma_{\varepsilon}, \varphi\right\}
$$

This stage requires the generation of simulated data, computation of a few selected moments which we discuss in Subsection 4.2.1, and the minimization of their distance from real data counterparts. It is similar to estimation by the Simulated Method of Moments (SMM) but we only generate one set of simulated data.

In this procedure, we simulate a data set for a given vector of parameters $(\Omega ; \beta, \Delta, \Lambda)$. Then, we create a vector of selected moments computed using the simulated data and calculate its distance to a vector of moments with the real data counterparts. Thus, optimization with respect to $\Omega$ takes place until we find the parameter vector that minimizes that distance.

Formally, let $\hat{m}$ denote the vector of moments computed from real data. Call the vector of their simulated counterparts $\tilde{m}(\Omega ; \beta, \Delta, \Lambda)$. Then, $\Omega$ is calibrated as

$$
\hat{\Omega}=\underset{\Omega}{\arg \min }(\tilde{m}(\Omega ; \beta, \Delta, \Lambda)-\hat{m})^{\prime}(\tilde{m}(\Omega ; \beta, \Delta, \Lambda)-\hat{m}) .
$$

\subsection{1 \\ Moments and Identification}

The following moments were selected to compose $\hat{m}$, all of them computed using RAIS: (i) the share of workers subjected to a high replacement rate (HRR); (ii) the job tenure standard deviation for workers who have quit their jobs before completing 6 months (SD6); (iii) the difference in the hazard rate for a termination without cause between the 6 th and the 4 th month of employment (H64).

We verify if those moments are truly informative about the parameters that we propose to calibrate by performing a similar analysis to the one conducted in Adda et al., 2017. It comprises to check the region of the objective function around the parameters resulted from the calibration. If too flat, it indicates that those moments are not that informative. In that case,

\footnotetext{
${ }^{2}$ The real return of the FGTS balance account was calculated by the own author dividing its monthly nominal return by the average monthly inflation between $01 / 2007$ and $12 / 2010$. The legislation sets its nominal return to $3 \%$ a.a. + TR. In monthly terms, the first one is equal to $0.246627 \% \mathrm{a} . \mathrm{m}$. and the second averaged $0.089893892 \% \mathrm{a} . \mathrm{m}$. in the period. The average monthly inflation was $0.418958333 \%$ a.m., as measured by the IPCA index.
} 
the parameters are not properly identified and any analysis relied on their values is questionable. The results are in Appendix C. Figure C.1 shows that the objective function responds to small variations in the parameters values resulted from the calibration, what suggests that the region they were found is not flat and reassures their identification.

In addition to that exercise, we provide a heuristic discussion about how the data can be combined with the model's structure to identify the parameters we want to calibrate.

First, the non-formal income, $b$, is determined by the HRR from each cell. That is because the higher this income is, the fewer the workers will be employed in equilibrium earning low wages. This pattern is explained due to the increase in the workers' reservation wages implied by a higher $b$.

Second, the standard deviation of the preference shocks, $\sigma_{\varepsilon}$, is determined by the SD6. Because these agreements are most likely to take place after eligibility for UI is met, which happens after the 6th month of employment, we restrict our attention to the voluntary quits that happen before that to avoid their mismeasurement. That is, we only consider the job quits before six months of employment. This way, we account for all the separations effectively voluntary to that point which, accordingly with our framework, are motivated by the preference shocks. Since these shocks increase the heterogeneity in the quitting time decisions in the model, such heterogeneity found in the real data is ideal to discipline that parameter.

Third, the probability of a successful fake layoff agreement, $\varphi$, is determined by H64. This difference in the hazard rate for termination without cause disciplines that parameter, because the higher the likelihood of a successful fake layoff agreement, the higher it is the value of quitting after eligible for UI, consequently, that difference calculated using simulated data will be bigger. We are not alone in choosing this particular timing to study the rise in the unemployment inflow around the UI eligibility threshold. Carvalho et al., 2018 uses the 4th month as control and the 6th as the treatment to perform one of their diff-in-diff in the article. Our choice of the 6th month should be obvious as it is the UI eligibility threshold established by the regulation. As to the choice of the 4th month, it is justified by what we discussed above plus by the existence of a probation period before that, as mentioned in Section 2.1.

\subsection{2}

\section{Parameters and Model fit}

Table 4.1 reports the parameter values found in the second step of the calibration. Those originated in the first step are in the Appendix B. The 
calibration reveals that the income from formal unemployment is higher than the statutory minimum wage in the formal sector. That becomes evident when the latter, 6.046072, is compared to the lowest $b$ value resulted from calibration, 6.391191. Their difference of $0.345119 \log$ points is considerable. Additionally, workers in the youngest age group, 18-25 years old, have relatively low stability in labor preferences while employed when compared to the other groups. For a given skill group, the dispersion of the preference shocks $\sigma_{\varepsilon}$ of the youngest are always closer to the highest value found than to the lowest one when it is not the highest itself. Finally, for workers in the same age group, the likelihood of a successful fake layoff agreement $\varphi$ increases with skill.

Table 4.2 reveals how the model fits the moments discussed in the previous subsection. It matches the QB6, understates HRR and overstates H64 for the majority of the cells. Figure 4.1 illustrates how the model fits the replacement rate distribution of the employees in the economy what includes non-targeted moments as well. We weight each cell by their total active contracts on December 31 of the years in the sample to aggregate our results. Non-aggregated results are in the Appendix E. The model understates the fraction of employees subjected to a high replacement rate in the economy. It overstates the share subjected to a low one. And fits well the proportion of employees in the intermediate replacement rate range.

Figure 4.2 shows how the model fits the job tenure distribution of the employed workers in the economy. It generates a similar pattern of higher concentration in the initial months and decay along the time. But it exaggerates both the degree of concentration and the speed of decay. The model's job tenure distribution displays higher sensitivity to the institutional incentives than what is observed in the data. The accentuated drop in the distribution at the UI eligibility threshold by six months reflects this fact. The model also generates an upward move in the distribution close to 12 months of job tenure which is explained by its limitation to fit some of the cells particularly. Again, refer to Appendix E to verify the results by cell. Finally, the model generates a high concentration in three months of employment unobserved in the data. We attribute this fact to the lack of the firm's side once its presence would raise the probability of termination without cause in the third month of employment, as discussed in Section 2.3.

Lastly, Figure 4.3 shows how the model fits the hazard function for terminations without cause in the economy. It generates a rise in the hazard rate at the UI eligibility threshold in the 6th month of employment, which is observed in the data. But it exaggerates the size of such rise. Additionally, it generates higher hazard rates from the 6 th to the 12 th month of employment 
than from the 13th to the 23th month - when laid-off workers are granted an additional payment of UI benefits. This is also observed in the data, but the model overstates the hazards in the former interval and understates them in the latter. Finally, the discussion in the last paragraph justifies the disparities at the 3rd and around the 12th month of employment.

\begin{tabular}{lc|cccc}
\hline & & Q1 & Q2 & Q3 & Q4 \\
\hline & $\mathrm{b}$ & 6.391191 & 7.199479 & 6.806681 & 6.695089 \\
18-25 years old & $\sigma_{\varepsilon}$ & 2.054621 & 1.649479 & 2.116183 & 2.01904 \\
& $\varphi$ & 0.271941 & 0.472951 & 0.570754 & 0.585144 \\
\hline & $\mathrm{b}$ & 7.584311 & 7.124994 & 7.060573 & 6.439442 \\
26-35 years old & $\sigma_{\varepsilon}$ & 2.4025 & 1.539427 & 1.791218 & 1.802352 \\
& $\varphi$ & 0.377479 & 0.527649 & 0.34258 & 0.606133 \\
\hline & $\mathrm{b}$ & 7.219294 & 6.629583 & 6.509146 & 7.178989 \\
36-49 years old & $\sigma_{\varepsilon}$ & 1.457542 & 1.620136 & 2.179574 & 1.287549 \\
& $\varphi$ & 0.443266 & 0.452045 & 0.467567 & 0.584991 \\
\hline
\end{tabular}

Table 4.1: Second step calibrated parameters.

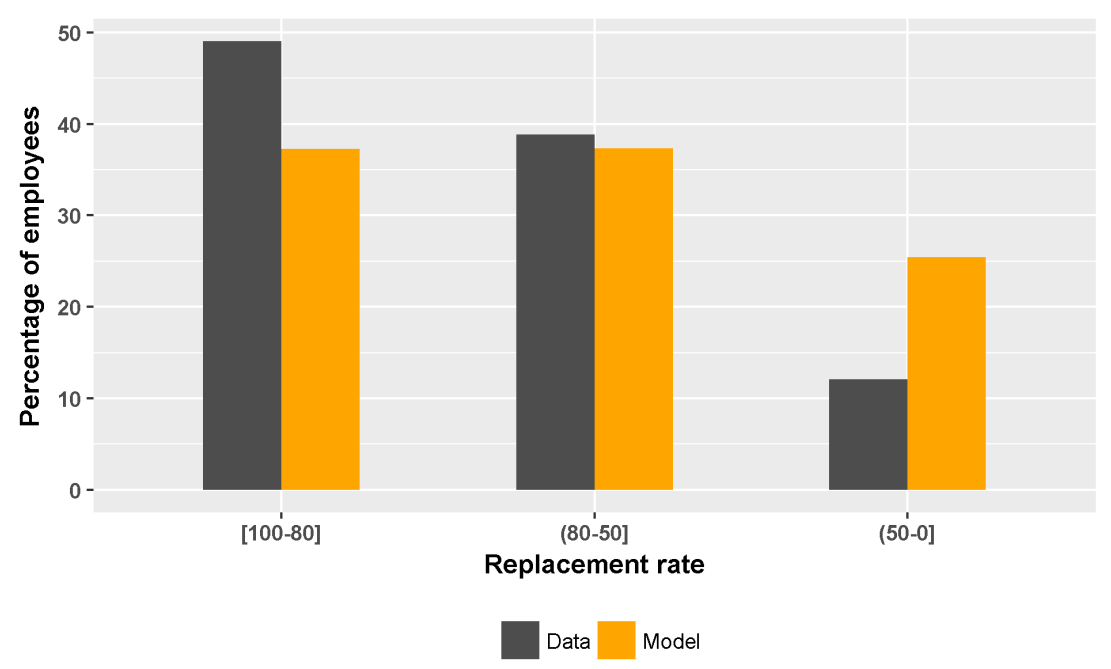

Figure 4.1: Replacement rate distribution of employed workers. 


\begin{tabular}{rc|cccccccc}
\hline & \multicolumn{2}{|c}{ Q1 } & \multicolumn{2}{c}{ Q2 } & \multicolumn{2}{c}{ Q3 } & \multicolumn{2}{c}{ Q4 } \\
\cline { 3 - 10 } & & Data & Model & Data & Model & Data & Model & Data & Model \\
\hline \multirow{3}{*}{ 18-25 years old } & QB6 & 1.361302 & 1.371989 & 1.369363 & 1.365331 & 1.36959 & 1.376945 & 1.385661 & 1.407824 \\
& H64 & 0.01715 & 0.001541 & 0.015532 & 0.083414 & 0.01237 & 0.067958 & 0.008454 & 0.034289 \\
\hline \multirow{5}{*}{ 26-35 years old } & QB6 & 1.350644 & 1.34027 & 1.365206 & 1.409736 & 1.366808 & 1.414593 & 1.386071 & 1.381484 \\
& H64 & 0.01677 & 0.008466 & 0.014073 & 0.168101 & 0.01122 & 0.014402 & 0.007625 & 0.017123 \\
\hline \multirow{3}{*}{ 36-49 years old } & QB6 & 1.353513 & 1.33177 & 1.359678 & 1.395179 & 1.357411 & 1.355521 & 1.376935 & 1.36575 \\
& HRR & 0.773846 & 0.652632 & 0.551834 & 0.307973 & 0.333442 & 0.199628 & 0.117265 & 0.049769 \\
& H64 & 0.015909 & 0.124641 & 0.013537 & 0.017311 & 0.010962 & 0.011915 & 0.007924 & 0.033896 \\
\hline
\end{tabular}

Table 4.2: Moments fit. 


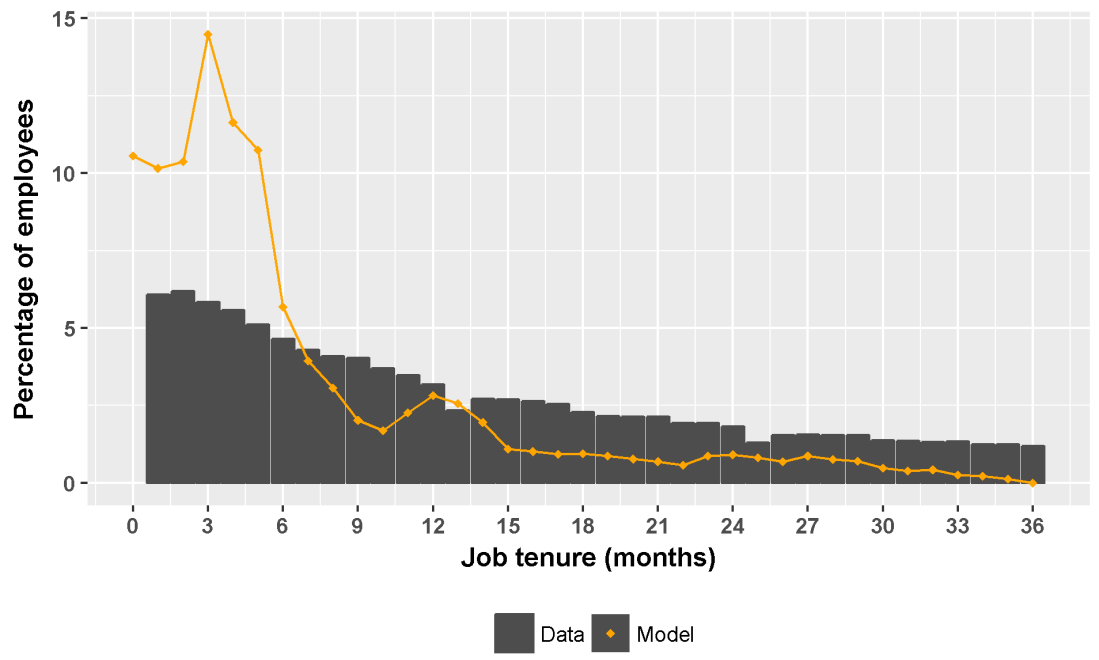

Figure 4.2: Job tenure distribution of employed workers.

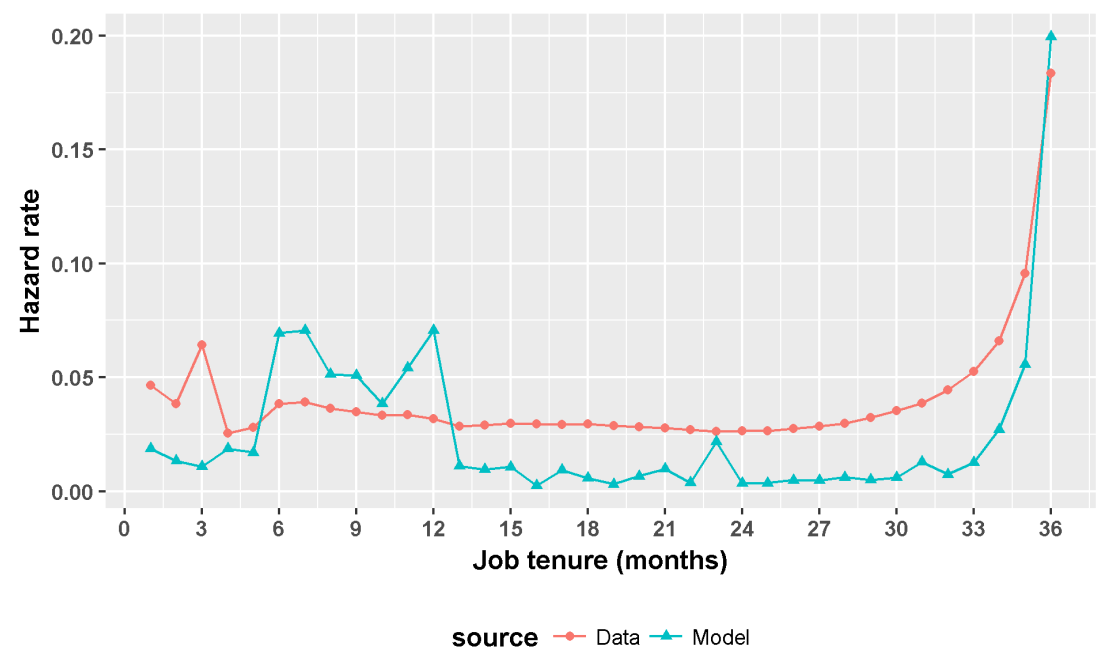

Figure 4.3: Termination without cause hazard function. 


\section{5}

\section{Counterfactual Analysis}

\section{1}

\section{Stricter eligibility}

The current eligibility criteria for the Brazilian UI program are not the same in the discussion in Section 2.1. Since July 2015, the eligibility threshold depends on the worker's history on benefits claims. Now, to claim unemployment benefits for the first time she needs at least 12 months of job tenure at the termination. For the second time, at least 9 months of formal employment. Beyond that, the requirement is the same as before, i.e. at least 6 months of job tenure at the termination. Importantly, the replacement rate schedule remains unchanged. Also, the number of monthly payments to receive respects the same job tenure intervals described in Section 2.1.

Inspired by this change in the Brazilian UI program, we use the model calibrated in Chapter 4 to conduct a counterfactual analysis in a scenario where the eligibility requirement is stricter than in the baseline. In the former case, at least 12 months of job tenure at termination is required to collect UI benefits. In the latter, the threshold is 6 months. We are interested in how the average wage, the average job tenure, and the turnover rate of the economy compare in those two scenarios. Importantly, since we do not account for the worker's history of benefits claims, our aggregate results should not be interpreted as the consequences of the real change in the UI program. The best we can do to assess these effects without adding a state variable in the model is to limit the analysis to the youngest group of workers. For this reason, we present results for workers 18-25 years old as well.

Table 5.1 reports the results for a stricter eligibility requirement to collect UI benefits. Changes in the average wage are in log points. Differences in the average job tenure are divided by the average in the baseline. The turnover rate is computed as the reason between total separations plus hires in the period and the number of employed workers. The changes in that rate $\times 100$ correspond to the variation in percentage points. All differences take the baseline values as reference. The first column in the table presents the aggregate results of the counterfactual exercise. Require 12 months of job tenure to collect UI benefits 
would raise the average wage in the formal sector in .035 log points compared to the baseline. It would also increase the average job tenure by $6.6 \%$ of the baseline's average and raise the turnover rate by 4.3 percentage points.

In our framework, wages are non-decreasing with job tenure. Thus, their averages changing in the same direction is not surprising. However, both the turnover rate and the average job tenure rising can be counter-intuitive. We provide the mathematical intuition to understand this in Appendix F. To put into words the turnover rate definition is the total number of hires and separations in the period divided by the number of employed workers. The change in the UI design alters the distributions of wages and job tenure of employed workers. But, it also varies the turnover rate components. In particular, the fraction of employed workers who voluntarily separate from their jobs (the quitters) changes. How it changes will shape the turnover rate response.

Figure 5.1 shows the scatter plot of the change in the fraction of quitters, $\mathrm{y}$-axis, versus the change in the average job tenure, $\mathrm{x}$-axis, for the age-skill cells. We measure the change in that fraction the same way we do to the turnover rate, that is the change $\times 100$ equals the variation in percentage points. The horizontal black line separates $y>0$ from $y<0$ and the vertical one separates $x<0$ from $x>0$. It is evident that the change in UI had heterogeneous effects on the average job tenure between cells. Also comes to attention that there are points in the 2nd and the 4th quadrants, where that fraction changed in the opposite direction of the change in the average job tenure. But there are also points in the 1st quadrant, where they both move in the same direction.

Figure 5.2 shows how the change in the fraction of quitters, $\mathrm{x}$-axis, relates to the change in the turnover rate, y-axis, for each age-skill cell. The blue line is a regression line fitting the points in the plot. It shows that the turnover rate response is strongly correlated with the change in that fraction. Figure 5.3 sums up the result. It plots the turnover change in the y-axis and the change in the average job tenure in the $\mathrm{x}$-axis of each cell. The same pattern found in Figure 5.1 is present there, what illustrates the point made in the discussion above.

Concluding the remarks on the aggregate results, Figure 5.4 exhibits how the hazard function of terminations without cause responds to the stricter eligibility requirement. The main change is the disappearing of the discontinuity at the 6th month of employment. Nonetheless, it is replaced by another one at the 4th month. That is the time when terminations without cause become costly for the employers and the workers gain some leverage to negotiate fake layoff agreements. Importantly, in a setting where firms can 
anticipate and respond to this behavior, this result would possibly be different.

Finally, we comment on the results for the workers 18-25 years old in the second column of Table 5.1. All statistics respond in the same direction as the aggregate results. But the changes are more intensive. Require 12 months of job tenure to collect UI benefits raises the average wage in the formal sector in .041 log points compared to the baseline. It also increases the average job tenure by $9.6 \%$ of the baseline's average and the turnover rate by 4.6 percentage points. Importantly, since workers usually enter the workforce in this age group, these results should be closer to the effects of the real change in the Brazilian UI program than the results in the first column of Table 5.1. We assert this because workers recently added to the workforce have never claimed UI benefits before what means that they are under the same eligibility threshold as the workers in this exercise.

Table 5.1: Stricter eligibility threshold: 12 months.

\begin{tabular}{|c|c|c|}
\hline Statistics change & Aggregate & $18-25$ years old \\
\hline Avg. Wage ${ }^{1}$ & 0.03566 & 0.04161 \\
\hline Avg. Tenure ${ }^{2}$ & 0.06602 & 0.096153 \\
\hline Turnover rate ${ }^{3}$ & 0.04383 & 0.046551 \\
\hline
\end{tabular}

All differences take the baseline values as reference. Results are weighted averages of the cell statistics. The weights are the total number of active contracts on December 31 of every year in the sample of each cell. The Aggregate column presents the results considering the 12 ageskill cells. The 18-25 years old column reports the findings considering only the cells in that age group. The turnover rate is calculated as total separations plus hires in the period divided by the number of employed workers.

${ }^{1}$ Changes in the average wage are in log points;

${ }^{2}$ Differences in the average job tenure are divided by the average in the baseline; ${ }^{3}$ Changes in the turnover rate $\times 100$ equals the variation in percentage points. 


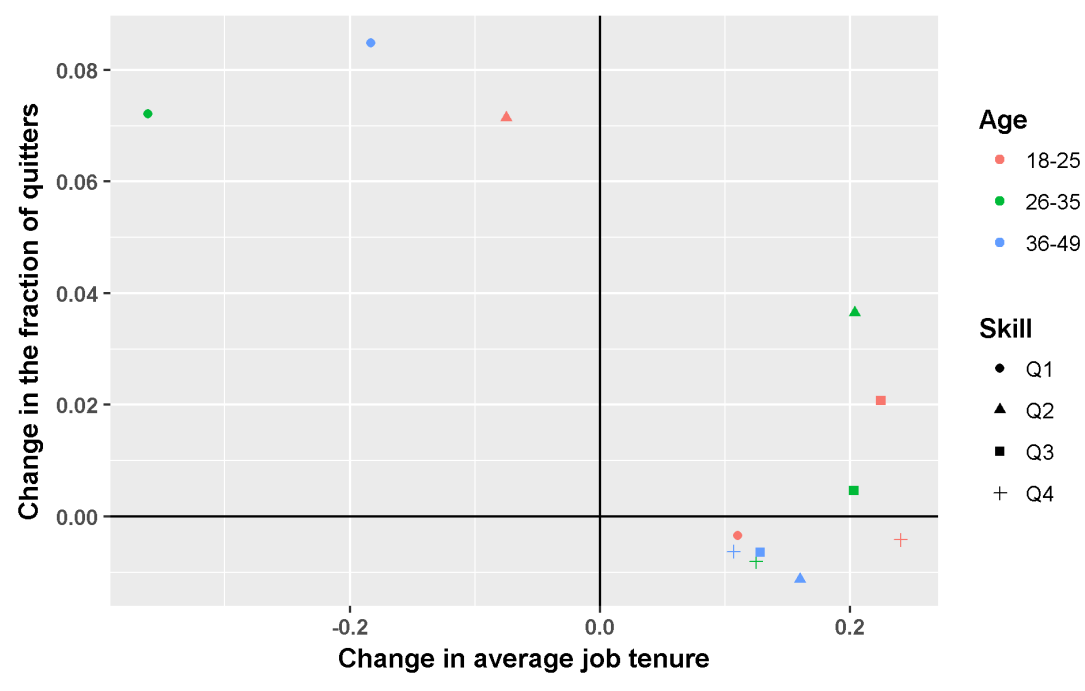

Figure 5.1: Scatter plot of the change in the fraction of the employed workers who voluntarily separate (quitters) of each cell versus their change in the average job tenure.

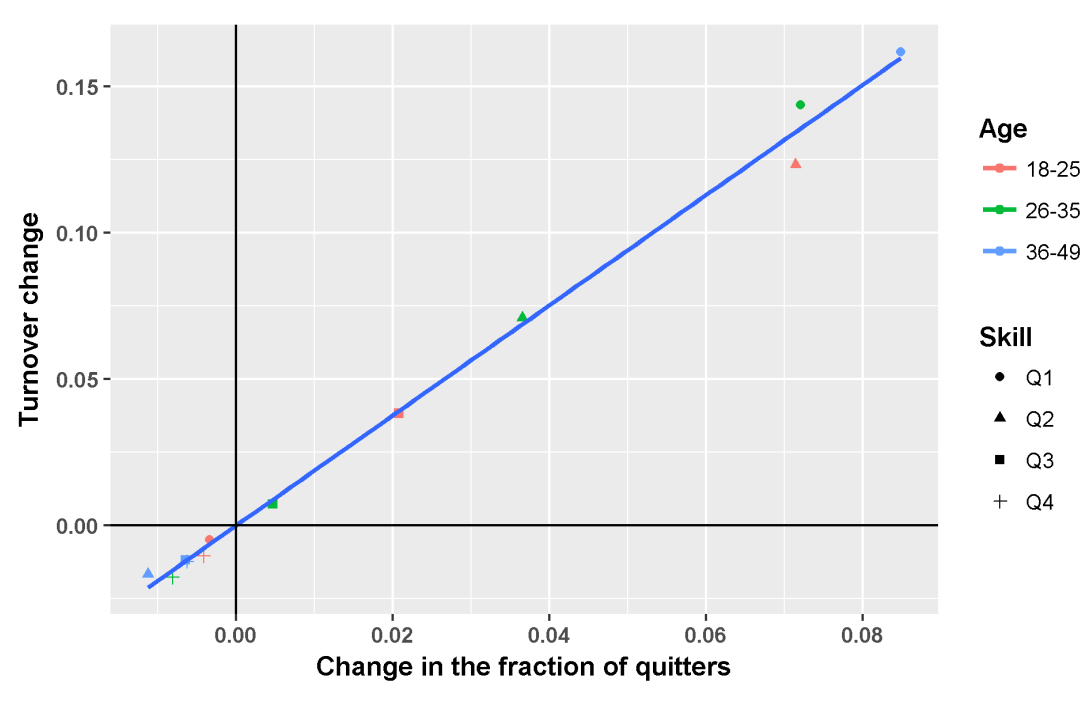

Figure 5.2: Scatter plot of the change in the turnover rate of each cell versus their change in the fraction of the employed workers who voluntarily separate (quitters). 


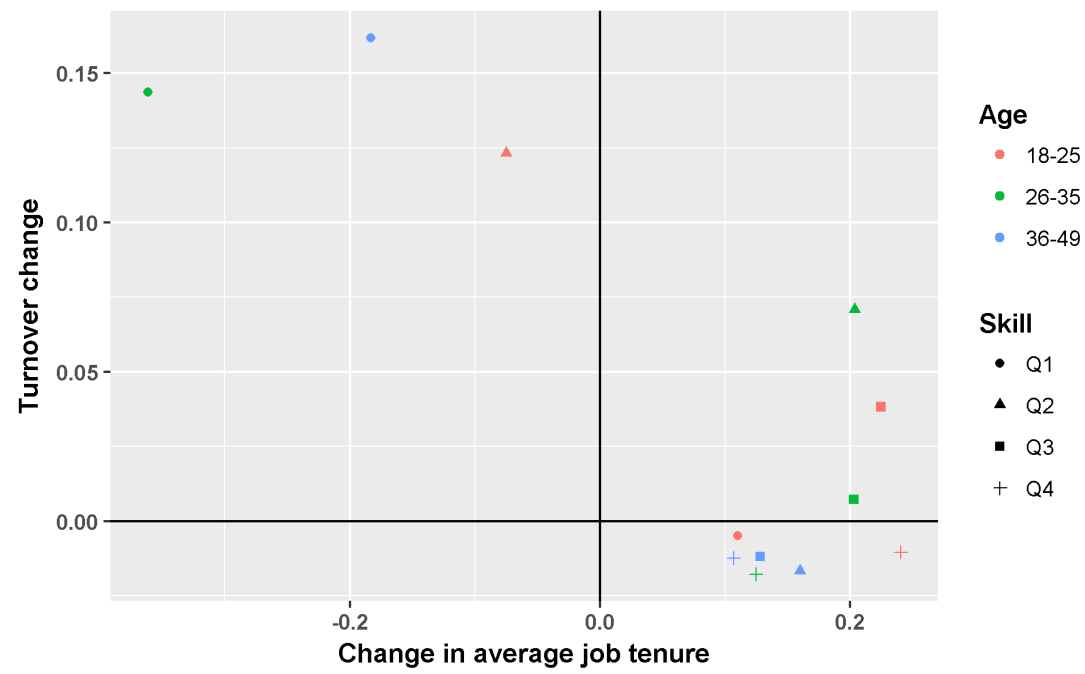

Figure 5.3: Scatter plot of the change in the turnover rate of each cell versus their change in the average job tenure.

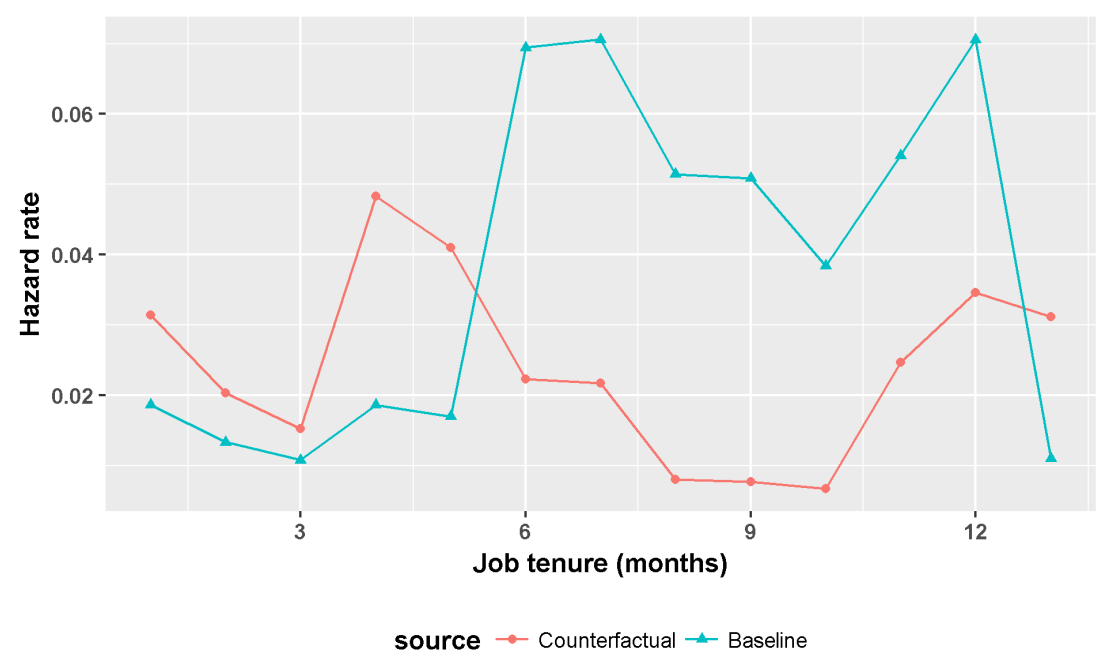

Figure 5.4: Hazard function of terminations without cause. 


\section{2}

\section{Homogeneous replacement rates}

In this section, we analyze the impact of different replacement rate schedules on the duration of employment relations. We build two counterfactual scenarios and evaluate the change in the average job tenure for the following wage ranges where the minimum wage is the numeraire: $[1,1.65),[1.65,2.75)$ and $[2.75,+\infty)$. These thresholds were discussed in Section 2.1. They appear in the replacement schedule of the Brazilian UI program. And we used them in this paper to define high, medium and low replacement rates as [100\%-80\%], (80\%-50\%] and (50\%-0\%], respectively.

In the first scenario we build, the replacement rate for eligible workers is $80 \%$. In the second one, it is $50 \%$. But in the baseline, the replacement rate schedule is the same as described in Section 2.1. Table 5.2 presents the results. It reports the change in the average job tenure as a fraction of the average in the baseline. We compute averages for each wage range by age-skill cell. Then, we take the weighted average keeping every cell composition of wage ranges as in the baseline. Finally, we subtract the result from the baseline average and divide by this same value.

The changes are very small, but they exhibit an interesting pattern. There is a negative relationship between the change in the UI benefits and the average employment duration. In the following, we refer to a rise in the replacement rate for a particular wage range if the new rate is higher than the midpoint of the correspondent replacement rate range we mentioned in the first paragraph. Thus, in the first column, the replacement rate is lower for the $[1,1.65)$ wage range but higher for the others. The average job tenure increased in the first wage range, dropped in the third and remain practically still in the second one for which the increase in the replacement rate was smaller than for the second one. Roughly, the same pattern is observed in the second column where the only range experiencing a rise in the replacement rate is the last one. The change for the $[1,1.65)$ wage range is an exception, though. In that case, the replacement rate dropped, but so did the average job tenure, which is consistent with the reduction in the UI benefits diminishing the attractiveness of the formal employment. 
Table 5.2: Homogeneous replacement rates: $80 \%$ and $50 \%$.

\begin{tabular}{lrr}
\hline Wage range & $80 \% \mathrm{RR}$ & $50 \% \mathrm{RR}$ \\
\hline$[1,1.65)$ & 0.00655 & -0.01003 \\
{$[1.65,2.75)$} & 0.000211 & 0.003568 \\
{$[2.75,+\infty)$} & -0.00613 & -0.00724 \\
\hline
\end{tabular}

The wage ranges are defined with the minimum wage as the numeraire. Results are weighted averages of the average job tenure of each wage range in every age-skill cell. Weights are the total number of active contracts on December 31 of every year in the sample for each cell times the wage range share in the cell in the baseline. The first column presents the change in the average job tenure with respect to the baseline average considering $80 \%$ replacement rate for eligible to UI workers. The second column does the same for a $50 \%$ replacement rate. Results are reported as a fraction of the baseline average. 


\section{6 \\ Conclusions}

We develop a model that consists of a labor market with search frictions, human capital accumulation, idiosyncratic labor disutility shocks and incorporates legislation details that determine eligibility for UI benefits. Workers are allowed to quit their jobs and they might do it to collect UI benefits. We calibrate it using Brazilian data and perform some counterfactual exercises.

In the first one, we evaluate the implications of rising the job tenure eligibility threshold to collect UI benefits in a similar way the Brazilian UI program changed recently. We find that, compared to the baseline, wages rise approximately $3.5 \%$ (.035 log points), the average tenure grows $6,6 \%$ and the turnover rate rises 4.3 percentage points. We comment on the fact that both the average tenure and the turnover rate moved in the same direction by arguing that it depends on how the policy modifies the fraction of employed workers who voluntarily separate from their jobs.

Additionally, we show the results of this exercise for workers 18-25 years old. We argue they can better approximate the effects of the actual change in the UI program for their group than the aggregate results for the economy. In this case, the average wage rises approximately $4.1 \%$, average job tenure grows $9.6 \%$ and the turnover rate rises 4.65 percentage points.

Finally, in the second exercise, we exchange the baseline replacement rate schedule for flat ones on two occasions. In the first one, the replacement rate is $80 \%$ of the wage, while in the second it is $50 \%$. We assess the impact these changes have on the average job tenure of workers in selected wage ranges. All of them mapped into replacement rate ranges in the baseline. We find that the changes in the replacement rate schedule have heterogeneous effects between the wage ranges. Further, these effects are negatively related to the change in the replacement rate of the wage range. Thus, there is a negative relationship between the change in the UI replacement rate and the average employment duration. 


\section{Bibliography}

Adda, J., Dustmann, C., and Stevens, K. (2017). The career costs of children. Journal of Political Economy, 125(2):293 - 337.

Assunção, J., Pinto, R. C., and Gonzaga, G. (2016). Tenure dependent firing costs and turnover in brazil. Unpublished Paper.

Atkinson, A. B. and Micklewright, J. (1991). Unemployment compensation and labor market transitions: A critical review. Journal of Economic Literature, 29(4):1679-1727.

Bagger, J., Fontaine, F., Postel-Vinay, F., and Robin, J.-M. (2014). Tenure, experience, human capital, and wages: $A$ tractable equilibrium search model of wage dynamics. American Economic Review, 104(6):1551-96.

Baker, M. and Rea, S. A. (1998). Employment spells and unemployment insurance eligibility requirements. The Review of Economics and Statistics, 80(1):80-94.

Bassanini, A. (2010). Inside the perpetual-motion machine: cross-country comparable evidence on job and worker flows at the industry and firm level. Industrial and Corporate Change, 19(6):2097-2134.

Bassanini, A. and Garnero, A. (2013). Dismissal protection and worker flows in oecd countries: Evidence from cross-country/cross-industry data. Labour Economics, $21: 25-41$.

Bassanini, A., Garnero, A., Marianna, P., and Martin, S. (2010). Institutional determinants of worker flows. OECD Social, Employment and Migration Working Papers, (107).

Bauer, T. K., Bender, S., and Bonin, H. (2007). Dismissal protection and worker flows in small establishments. Economica, 74(296):804-821.

Blanchard, O. and Portugal, P. (2001). What hides behind an unemployment rate: Comparing portuguese and u.s. labor markets. The American Economic Review, 91(1):187-207.

BLS (2018). Real earnings - june 2018. Technical report, U.S. Department of Labor, Bureau of Labor Statistics. 
Carvalho, C. C., Corbi, R., and Narita, R. (2018). Unintended consequences of unemployment insurance: Evidence from stricter eligibility criteria in brazil. Economics Letters, 162:157 - 161 .

Chade, H., Eeckhout, J., and Smith, L. (2017). Sorting through search and matching models in economics. Journal of Economic Literature, 55(2):493-544.

Christofides, L. N. and McKenna, C. J. (1996). Unemployment insurance and job duration in canada. Journal of Labor Economics, 14(2):286-312.

CNI (2016). Retratos da sociedade brasileira 30: Rotatividade no mercado de trabalho. Technical Report 30, Confederação Nacional da Indústria.

Corseuil, C. H., Foguel, M., Gonzaga, G., and Ribeiro, E. P. (2014). Youth labor market in brazil through the lens of the flow approach. Anais do xli encontro nacional de economia [proceedings of the 41st brazilian economics meeting], ANPEC - Associação Nacional dos Centros de Pós-Graduação em Economia [Brazilian Association of Graduate Programs in Economics].

Davis, S. J. and Haltiwanger, J. (2014). Labor market fluidity and economic performance. NBER Working Papers 20479, National Bureau of Economic Research, Inc.

de Barros, R. P., Corseuil, C. H., and Foguel, M. (2001). Os incentivos adversos e a focalização dos programas de proteção ao trabalhador no brasil. Planejamento e Políticas Públicas, (22):3-45.

Doornik, B. V., Schoenherr, D., and Skrastins, J. (2018). Unemployment insurance, strategic unemployment, and firm-worker collusion. Available at SSRN: https://ssrn.com/abstract $=3168769$.

Foster, L., Haltiwanger, J., and Krizan, C. (2006). Market selection, reallocation, and restructuring in the u.s. retail trade sector in the 1990s. The Review of Economics and Statistics, 88(4):748-758.

Fredriksson, P. and Holmlund, B. (2006). Improving incentives in unemployment insurance: A review of recent research. Journal of Economic Surveys, 20(3):357386.

Fuller, D. L., Ravikumar, B., and Zhang, Y. (2015). Unemployment insurance fraud and optimal monitoring. American Economic Journal: Macroeconomics, $7(2): 249-290$. 
Gerard, F. and Gonzaga, G. (2016). Informal labor and the efficiency cost of social programs: Evidence from the brazilian unemployment insurance program. Working Paper 22608, National Bureau of Economic Research.

Gonzaga, G. and Guanziroli, T. (2017). Returns to experience across tasks: Evidence from brazil. Technical report.

Gonzaga, G., Maloney, W. F., and Mizala, A. (2003). Labor turnover and labor legislation in brazil [with comments]. Economía, 4(1):165-222.

Haltiwanger, J., Scarpetta, S., and Schweiger, H. (2014). Cross country differences in job reallocation: The role of industry, firm size and regulations. Labor Economics, 26:11-25.

Jung, P. and Kuhn, M. (2014). Labour market institutions and worker flows: Comparing germany and the us. The Economic Journal, 124(581):1317-1342.

Karni, E. (1999). Optimal unemployment insurance: A survey. Southern Economic Journal, 66(2):442-465.

Kugler, A. (1999). The impact of firing costs on turnover and unemployment: Evidence from the colombian labour market reform. International Tax and Public Finance, 6(3):389-410.

Kugler, A. and Pica, G. (2008). Effects of employment protection on worker and job flows: Evidence from the 1990 italian reform. Labour Economics, 15(1):78 $-95$.

Kugler, A. and Saint-Paul, G. (2004). How do firing costs affect worker flows in a world with adverse selection? Journal of Labor Economics, 22(3):553-584.

Light, A. and Omori, Y. (2004). Unemployment insurance and job quits. Journal of Labor Economics, 22(1):159-188.

Lise, J., Meghir, C., and Robin, J.-M. (2016). Matching, sorting and wages. Review of Economic Dynamics, (19):63-87.

Martin, J. and Scarpetta, S. (2012). Setting it right: Employment protection, labour reallocation and productivity. De Economist, 160(2):89-116.

McCall, J. (1970). Economics of information and job search. The Quarterly Journal of Economics, 84(1):113-126.

Narita, R. (2017). Self-employment in developing countries: A search-equilibrium approach. RR, Review of Economic Dynamics. 
OECD (2009). OECD Employment Outlook 2009.

Rebollo-Sanz, Y. (2012). Unemployment insurance and job turnover in spain. Labour Economics, 19(3):403 - 426.

Ribas, R. P. and Soares, S. S. D. (2008). Sobre o painel da pesquisa mensal do emprego (pme) do ibge. Technical Report 1348, IPEA.

Rogerson, R., Shimer, R., and Wright, R. (2005). Search-theoretic models of the labor market: A survey. Journal of Economic Literature, 43(4):959-988.

Rosen, S. (1986). Chapter 12 the theory of equalizing differences. volume 1 of Handbook of Labor Economics, pages 641 - 692. Elsevier.

Schmieder, J. F. and von Wachter, T. (2016). The effects of unemployment insurance benefits: New evidence and interpretation. Annual Review of Economics, 8(1):547-581.

Tatsiramos, K. and van Ours, J. C. (2014). Labor market effects of unemployment insurance design. Journal of Economic Surveys, 28(2):284-311.

Topel, R. H. and Welch, F. (1980). Unemployment insurance: Survey and extensions. Economica, 47(187):351-379.

van den Berg, G. (1990). Search behaviour, transitions to nonparticipation and the duration of unemployment. Economic Journal, 100(402):842-65.

Walker, W. R. (2011). Environmental regulation and labor reallocation: Evidence from the clean air act. The American Economic Review: Papers Proceedings, 101(3):442-447.

Wang, C. and Williamson, S. D. (2002). Moral hazard, optimal unemployment insurance, and experience rating. Journal of Monetary Economics, 49(7):1337 $-1371$.

Zhang, M. and Faig, M. (2012). Labor market cycles, unemployment insurance eligibility, and moral hazard. Review of Economic Dynamics, 15(1):41 - 56.

Zhang, M. and Pan, J. (2017). Ui eligibility rule, moral hazard, and optimal unemployment transfer scheme. Macroeconomic Dynamics, page 1-36.

Zweimüller, J. (2018). Unemployment insurance and the labor market. Labour Economics. 


\section{Data Appendix}

The main data source used in this paper is the Registro Anual de Informações Sociais (RAIS), an administrative database collected by the Ministry of Labor that contains information on the universe of formal labor contracts. Additionally, we use the survey Pesquisa Mensal do Emprego (PME) conducted by Instituto Brasileiro de Geografia e Estatística (IBGE). In both RAIS and PME we keep workers with 18-49 years old and exclude public sector, military and civil construction from the sample ${ }^{1}$. In RAIS we only keep open-ended contracts with 30 to 50 weekly hours of work. For consistency, we apply the same restriction in PME to formal employment (i.e., employment with the working card signed). We truncate the formal job tenure distribution at 36 months and round the job tenure variable in RAIS. This latter restriction is justified because it is the relevant horizon considered in the legislation for the payment of UI benefits.

Exclusively in RAIS, we drop the open-ended contracts terminated due to expiration, as well as the zero and missing wage observations. In the remaining contracts, we input the correspondent monthly minimum wage as the wage when the former is bigger than the latter - a small fraction of the observations. Additionally, to use the information on education, one must choose a way to give consistency to the data, as negative variations and large steps in qualification are observed between years in the raw data. To deal with this, we take each worker's minimum education mode in a year, compare it to her last education level observed and update it if smaller than the former.

\footnotetext{
${ }^{1}$ Excluding public sector and the military is common practice, rather the civil construction exclusion is justified by the higher levels of turnover when compared to the remaining sectors (i.e., retail, manufacturing, and services) revealing a different dynamic in the market. We still keep $3 / 4$ of the data by adding this exclusion.
} 


\section{B}

\section{Calibration Appendix}

This appendix provides the details of the parameters calibrated in the first step of the procedure.

We follow Narita (2017) to build labor market transitions using the PME and calibrate the transition parameters of the model, $\alpha$ and $\delta$. Due to data limitation, we are only able to calibrate the transitions by age cell. We use Ribas and Soares (2008) algorithm to identify individuals in the survey and we keep only their first two interviews in the sample (i.e., following them for a month). We pool the monthly data from January 2007 to December 2010 to build dummies to the following states: (i) formal employment; (ii) formal unemployment. Transition indicators are then created accordingly to the individual's initial state and the one in the following month. We consider (i) job-to-unemployment, (ii) unemployment-to-job and (iii) voluntary unemployment as transitions, where they are all relative to the formal sector. This way, we have averages representing the proportion of workers involuntarily separated from their formal employment and the proportion of formal unemployed that enters formal employment monthly, which we use directly in the model.

For the wage growth parameters calibration, $\gamma_{1}, \gamma_{2}, \gamma_{3}$, we estimate mincer equations using RAIS. We use only active contracts in December 31 of the years in the sample period. We control for both education level (less than high school, high school and college plus) and year effects and define yearly tenure indicators for the following cases $0 \leq$ tenure $<12,12 \leq$ tenure $<24$, $24 \leq$ tenure $<36$ and tenure $=36$. Finally, the dependent variable used is the $\log$ of the real wage in December, which is calculated in 12/2010 Brazilian Reais.

The initial wage offer distribution parameters, $\bar{w}, \sigma_{w}, w_{\text {min }}$, are calibrated according to the distribution of the log of the contractual wage observed in each cell in RAIS. We keep only contracts initiated on each year in the sample period, we drop the zero or missing contractual wage observations and we restrict the sample to contracts that establish monthly wages to avoid inconsistencies. The parameters are the average, the standard deviation and the minimum of this distribution, respectively. Contractual wages are also calculated in 12/2010 Brazilian Reais. 
In the following we report the output resulted from each of the procedures described above.

\begin{tabular}{cccc}
\hline & $18-25$ & $26-35$ & $36-49$ \\
\cline { 2 - 4 }$\alpha$ & 0.076480 & 0.075505 & 0.049681 \\
$\delta$ & 0.047964 & 0.035644 & 0.035614 \\
\hline
\end{tabular}

Table B.1: Transition parameters. PME 01/2007-12/2010.

\begin{tabular}{lcccc}
\hline & $\mathrm{Q} 1$ & $\mathrm{Q} 2$ & $\mathrm{Q} 3$ & $\mathrm{Q} 4$ \\
\hline$\gamma_{1}$ & 0.055004 & 0.058489 & 0.088541 & 0.111574 \\
& $(0.000262)$ & $(0.000295)$ & $(0.000386)$ & $(0.000584)$ \\
$\gamma_{2}$ & 0.088878 & 0.101180 & 0.156707 & 0.207237 \\
& $(0.000388)$ & $(0.000409)$ & $(0.000534)$ & $(0.000729)$ \\
$\gamma_{3}$ & 0.110207 & 0.111059 & 0.192619 & 0.266310 \\
& $(0.001695)$ & $(0.001629)$ & $(0.002167)$ & $(0.002655)$ \\
\hline $\mathrm{N}$ & 5980823 & 7641031 & 4895416 & 4151755 \\
$\mathrm{Adj} .-R^{2}$ & 0.053 & 0.046 & 0.066 & 0.179 \\
$R^{2}$ & 0.053 & 0.046 & 0.066 & 0.179 \\
\hline
\end{tabular}

Table B.2: Wage growth parameters, 18-25 years old. RAIS 2007-2010. 


\begin{tabular}{lcccc}
\hline & Q1 & Q2 & Q3 & Q4 \\
\hline$\gamma_{1}$ & 0.051214 & 0.061466 & 0.083120 & 0.085685 \\
& $(0.000294)$ & $(0.000400)$ & $(0.000420)$ & $(0.000549)$ \\
$\gamma_{2}$ & 0.079497 & 0.100710 & 0.135271 & 0.156611 \\
& $(0.000379)$ & $(0.000492)$ & $(0.000508)$ & $(0.000623)$ \\
$\gamma_{3}$ & 0.100876 & 0.118226 & 0.172531 & 0.201187 \\
& $(0.001430)$ & $(0.001699)$ & $(0.001706)$ & $(0.001973)$ \\
\hline $\mathrm{N}$ & 5495199 & 6148807 & 5704930 & 6916936 \\
Adj.- $R^{2}$ & 0.058 & 0.066 & 0.066 & 0.249 \\
$R^{2}$ & 0.058 & 0.066 & 0.066 & 0.249 \\
\hline
\end{tabular}

Table B.3: Wage growth parameters, 26-35 years old. RAIS 2007-2010.

\begin{tabular}{lcccc}
\hline & Q1 & Q2 & Q3 & Q4 \\
\hline$\gamma_{1}$ & 0.045741 & 0.061946 & 0.076081 & 0.078432 \\
& $(0.000338)$ & $(0.000590)$ & $(0.000563)$ & $(0.000763)$ \\
$\gamma_{2}$ & 0.070500 & 0.101950 & 0.121239 & 0.134173 \\
& $(0.000415)$ & $(0.000697)$ & $(0.000655)$ & $(0.000851)$ \\
$\gamma_{3}$ & 0.100639 & 0.142810 & 0.174757 & 0.203022 \\
& $(0.001506)$ & $(0.002270)$ & $(0.002064)$ & $(0.002555)$ \\
\hline $\mathrm{N}$ & 4127164 & 3165458 & 3563412 & 4488349 \\
Adj. $-R^{2}$ & 0.044 & 0.068 & 0.058 & 0.279 \\
$R^{2}$ & 0.044 & 0.068 & 0.058 & 0.279 \\
\hline
\end{tabular}

Table B.4: Wage growth parameters, 36-49 years old. RAIS 2007-2010.

\begin{tabular}{lc|cccc}
\hline & & Q1 & Q2 & Q3 & Q4 \\
\hline \multirow{2}{*}{ 18-25 years old } & $\bar{w}$ & 6.364972 & 6.453359 & 6.519346 & 6.858898 \\
& $\sigma_{w}$ & 0.188082 & 0.244079 & 0.277490 & 0.514565 \\
\hline \multirow{2}{*}{ 26-35 years old } & $\bar{w}$ & 6.387139 & 6.517912 & 6.635773 & 7.167553 \\
& $\sigma_{w}$ & 0.217221 & 0.321473 & 0.355147 & 0.667116 \\
\hline \multirow{2}{*}{ 36-49 years old } & $\bar{w}$ & 6.388528 & 6.540131 & 6.682557 & 7.266923 \\
& $\sigma_{w}$ & 0.222239 & 0.353553 & 0.380947 & 0.759105 \\
\hline
\end{tabular}

Table B.5: Initial wage offer distribution. RAIS 2007-2010. 


\section{C}

\section{Identification Appendix}

We verify if the chosen moments are truly informative about the parameters that we propose to calibrate by performing a similar analysis to the one conducted in Adda et al. (2017). It comprises to check the region of the objective function around the parameters resulted from the calibration. If too flat, it indicates that those moments are not too informative. In that case, the parameters are not properly identified and any analysis relied on their values is questionable. We evaluate the objective function varying one parameter calibrated in the second step at a time and compare it to its value at the calibrated vector. We choose .1, .2 and 1 percentage variations in the parameters to run this exercise. We do it for the 12 age-skill cells and obtain a distribution of responses for each parameter and every variation. Figure C.1 shows the results. The objective function does respond to small variations in the parameters values resulted from the calibration, what suggests that the region they were found is not flat and reassures their identification.

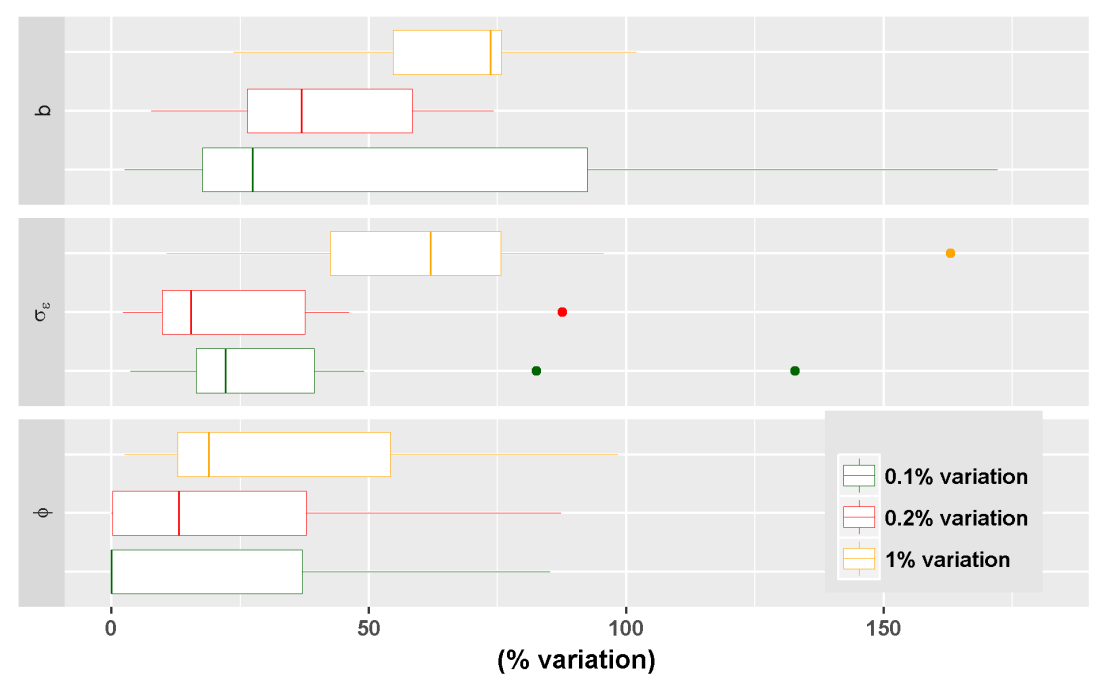

Figure C.1: Sensitivity of the objective function 
D

\section{Simulation Appendix}

This appendix describes the simulation procedure we use to obtain the simulated data used in the second step calibration. We simulate $\mathrm{I}=20,000$ workers for $\mathrm{T}=336$ months all starting as unemployed.

The simulation is conducted in the following way. At each new simulated period we add the following information to the record of each individual worker: her employment status (i.e., employed or unemployed), her wage, her job tenure, the idiosyncratic preference shock and in the case of a separation the reason why and if it was by fake layoff agreement.

Each period, every employed worker draw a preference shock from the distribution $N\left(0, \sigma_{\varepsilon}\right)$ and choose whether to quit or remain employed. The quit can proceed under a fake layoff agreement (probability $\varphi$ ), but the worker's employment status is independent of the success of the agreement. Remaining employed there is a possibility of receive a job destruction shock $(\delta)$ and be separated involuntarily. For those who decide to quit, we update their employment status, the reason of separation and the fake layoff indicator. The latter two, accordingly to the success of the agreement. For those separated involuntarily, we only update their status and the reason of separation. The rest of the employed workers keep their jobs for the next period and we only update their wages and job tenure.

Importantly, as we truncate the job tenure distribution in the data at 36 months we do not let the workers stay employed beyond that in the simulations. In that case, workers who attain 36 months of job tenure will be substituted for unemployed new born workers in the next period if they choose not to quit and do not receive a job destruction shock. For consistency, we also define a continuation value for the employment at 36 months. We assume that after the 36 months, the uncertainty related to the preferences about the jobs stops and the preference shocks are equal to 0 . Additionally, the value of employment is constant, $\mathrm{V}_{T}$, and the workers remain employed for $n$ periods, when they are involuntarily separated. We set $n$ accordingly to the 90 th percentile of the job tenure distribution of the employed workers $t^{n}$ in each cell. That is, $n=t^{*}-36$. For $n>0$, 


$$
\begin{aligned}
& \mathrm{V}_{T}=w+g(36)+\beta(1-\delta) \mathrm{V}_{T}+\cdots+\beta^{n-1}(1-\delta)^{n-1} \mathrm{~V}_{T}+ \\
& +\beta^{n}(1-\delta)^{n-1} \delta L\left(w, t^{*}\right) \\
& \mathrm{V}_{T}=\frac{w+g(36)+\beta^{n}(1-\delta)^{n-1} \delta L\left(w, t^{*}\right)}{2-\frac{1-[\beta(1-\delta)]^{n}}{1-\beta(1-\delta)}}
\end{aligned}
$$

Otherwise, $\mathrm{V}_{T}=0$. TableD.1 presents the values we used.

Finally, in each new period, unemployed workers can receive a job offer (with probability $\alpha$ ). In that case, we update their status, wages and set their job tenure to 0 .

Table D.1: 90th percentile of the job tenure distribution of employed workers.

\begin{tabular}{lcccc}
\hline & Q1 & Q2 & Q3 & Q4 \\
\cline { 2 - 5 } 18-25 years old & 32 & 36 & 38 & 43 \\
26-35 years old & 65 & 77 & 80 & 91 \\
36-49 years old & 109 & 142 & 152 & 212 \\
\hline
\end{tabular}

Employed workers are the active contracts on December 31 in RAIS. 
E

\section{Model Fit Appendix}

This appendix brings the model fit objects in terms of age-skill cells.
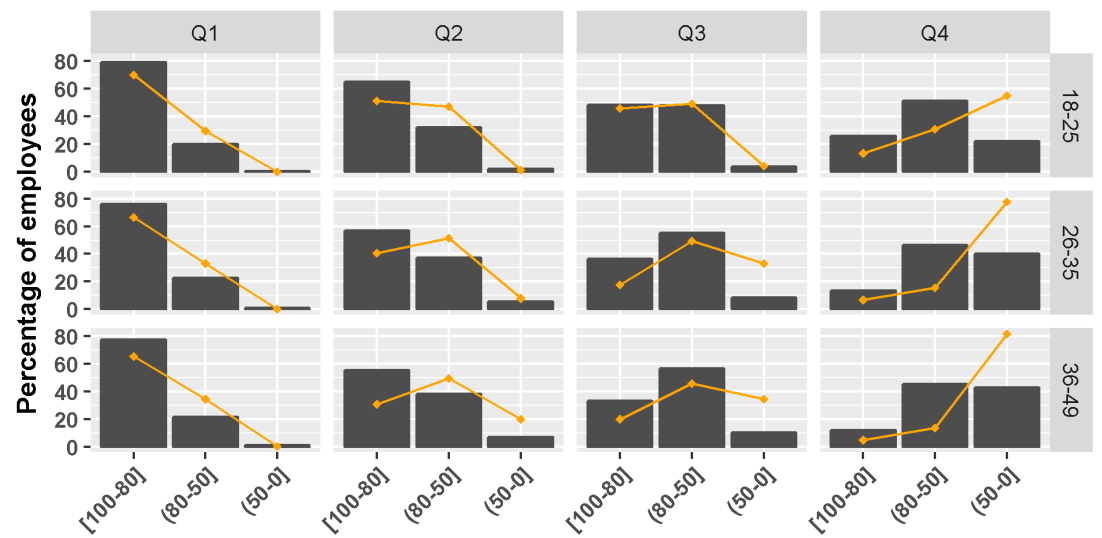

Replacement rate

Data - Model

Figure E.1: Replacement rate distribution of employed workers.

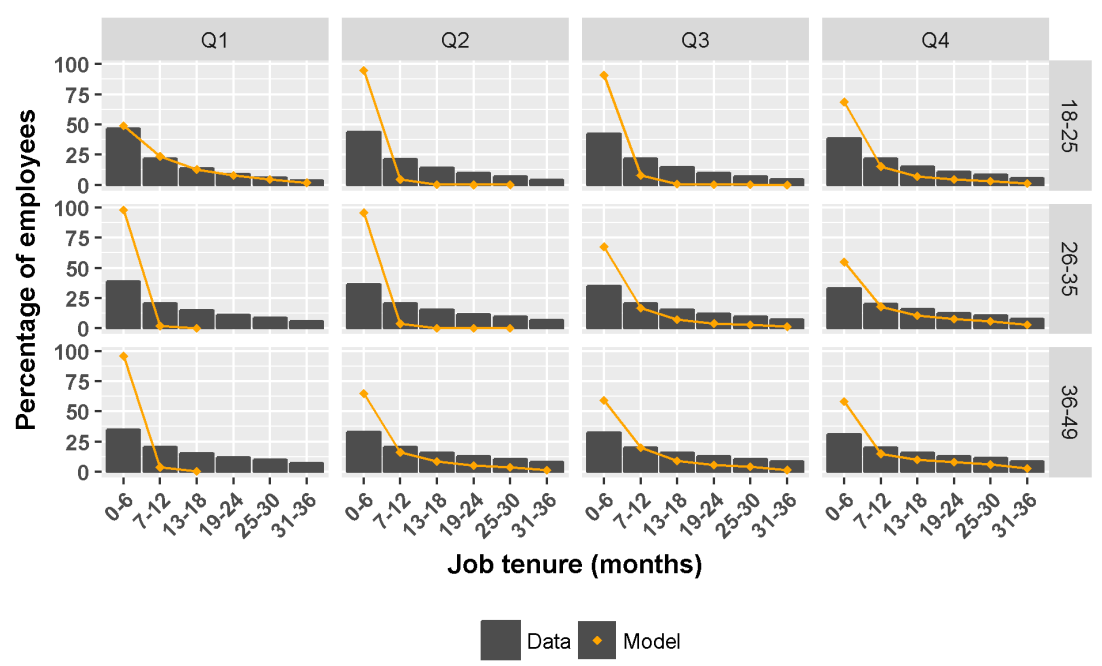

Figure E.2: Job tenure distribution of employed workers. 


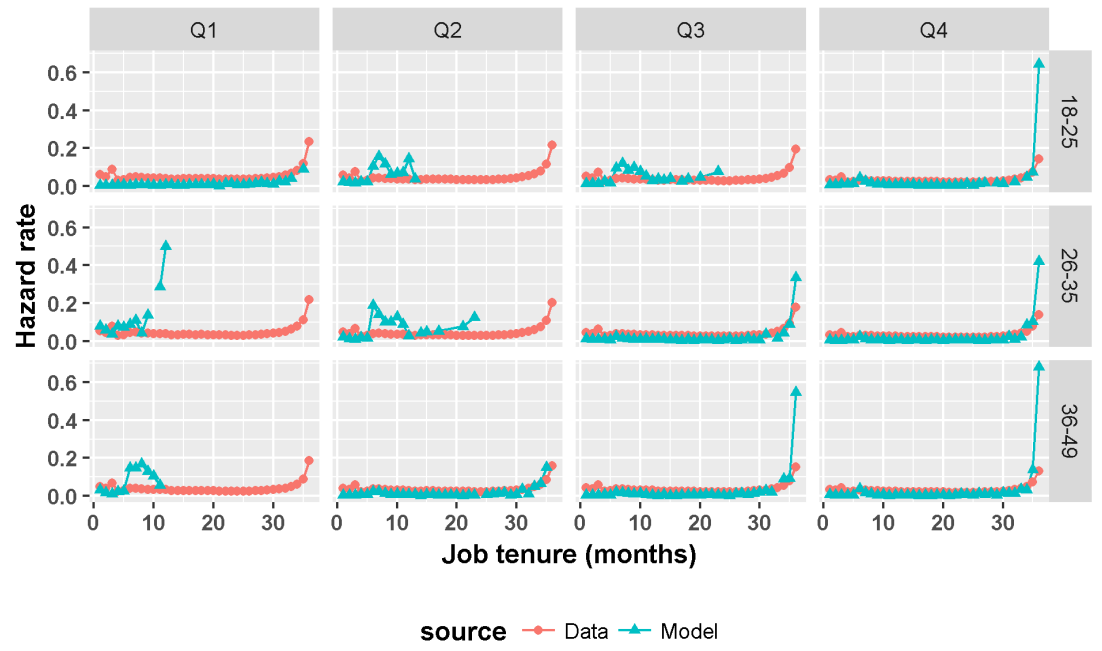

Figure E.3: Termination without cause hazard function.

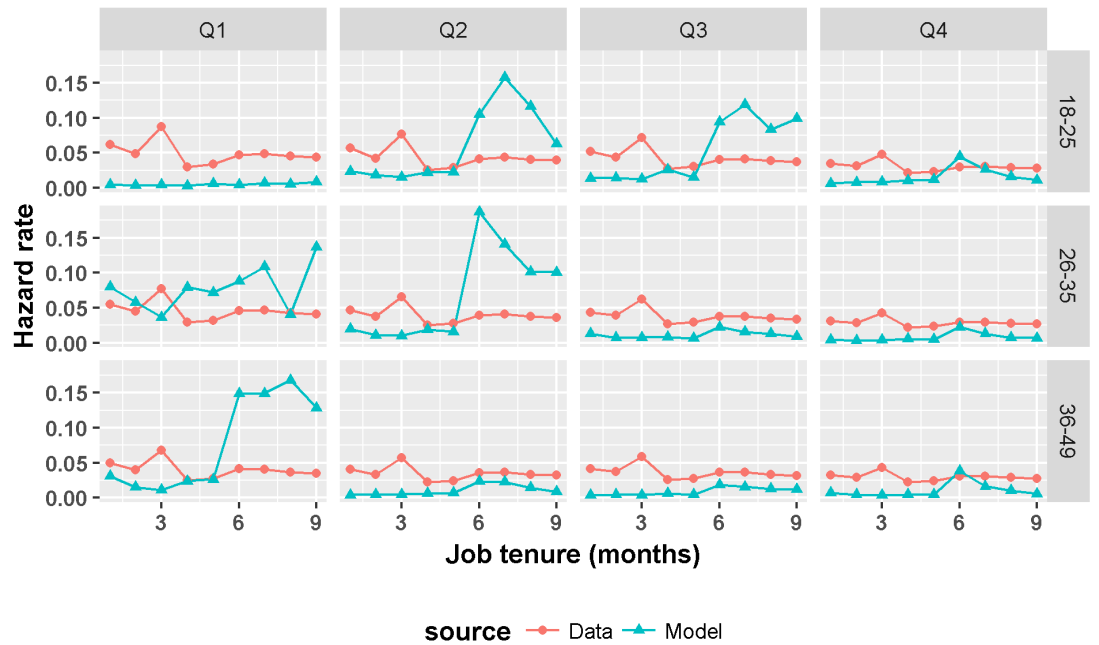

Figure E.4: Termination without cause hazard function for the first 9 months of employment relation. 


\begin{tabular}{lcccccccc}
\hline & \multicolumn{2}{c}{ Q1 } & \multicolumn{2}{c}{ Q2 } & \multicolumn{2}{c}{ Q3 } & \multicolumn{2}{c}{ Q4 } \\
\cline { 2 - 9 } & Data & Model & Data & Model & Data & Model & Data & Model \\
\cline { 2 - 9 } 18-25 years old & 0.103286 & 0.163957 & 0.092631 & 0.375466 & 0.090178 & 0.300102 & 0.074701 & 0.221775 \\
26-35 years old & 0.090887 & 0.748391 & 0.081355 & 0.352979 & 0.078647 & 0.273316 & 0.065311 & 0.172006 \\
36-49 years old & 0.08047 & 0.409125 & 0.072456 & 0.210822 & 0.071952 & 0.183542 & 0.061255 & 0.191489 \\
\hline
\end{tabular}

Table E.1: Turnover rate.

\begin{tabular}{lccccccccc}
\hline & \multicolumn{2}{c}{ Q1 } & \multicolumn{2}{c}{ Q2 } & \multicolumn{2}{c}{ Q3 } & \multicolumn{2}{c}{ Q4 } \\
\cline { 2 - 9 } & Data & Model & Data & Model & Data & Model & Data & Model \\
\cline { 2 - 9 } 18-25 years old & 0.013906 & 0.023836 & 0.011141 & 0.075737 & 0.01003 & 0.048394 & 0.008521 & 0.025143 \\
26-35 years old & 0.010536 & 0.214666 & 0.009032 & 0.067561 & 0.008271 & 0.067485 & 0.007516 & 0.020938 \\
36-49 years old & 0.007865 & 0.092972 & 0.006647 & 0.043613 & 0.006198 & 0.030333 & 0.005234 & 0.023145 \\
\hline
\end{tabular}

Table E.2: Share of employed workers that quit (separate without agreement). 


\section{$\mathbf{F}$}

\section{Turnover Mathematical Appendix}

This Appendix develops and analyzes the turnover rate derivative with respect to the fraction of employed workers who voluntarily separate from their jobs (quitters). Additionally, we provide some intuition about what could affect that fraction.

Define the turnover rate of period $t$ as total hires and separations in that period divided by the number of employed workers. That is,

$$
\text { turnover }_{t}=\frac{\text { hires }_{t}+\text { separations }_{t}}{\text { employment }_{t}} \text {. }
$$

The number of workers in the economy is constant. Call $e m p_{t}$ the mass of employed workers in period $t$. It can be written as,

$$
e m p_{t}=(1-\delta)(1-\psi) e m p_{t-1}+\alpha\left(1-e m p_{t-1}\right)+\alpha \psi e m p_{t-1} .
$$

$\alpha$ is the probability with an unemployed finds a job, $\delta$ is the probability with an employed worker who decided not to quit loses his job, and $\psi$ is the fraction of workers who quit their jobs every period. To simplify the exposition, we assume the latter to be constant in time. The mass of employed workers in period $t$ is given by the mass of employed workers in the previous period that did not quit, nor lost their jobs, plus the mass of workers who did not had a job in $t-1$ but found one, and the mass of workers who did have a job in the last period but quitted and found another one for this period.

The mass of hires and separations in period $t$ respectively hire $e_{t}$ and $\operatorname{sep}_{t}$ can be written as:

$$
\begin{aligned}
& \operatorname{hire}_{t}=\alpha\left(1-e m p_{t-1}\right)+\alpha \psi e m p_{t}, \\
& \operatorname{sep}_{t}=\psi e m p_{t}+\delta(1-\psi) e m p_{t} .
\end{aligned}
$$

That is, the mass of hires in period $t$ are given by the fraction $\alpha$ of the unemployed in period $t-1$ plus the $\alpha$ fraction of those workers who have quit this period but already found a job. The mass of separations in period $t$ equals the fraction $\psi$ of the employed workers who quit their jobs in this 
period plus the workers who did not quit, but still lost their jobs $\delta(1-\psi) e m p_{t}$. In the steady state,

$$
\begin{aligned}
& \operatorname{emp}(\psi)=\frac{\alpha}{1-(1-\delta-\alpha)(1-\psi)} \\
& \operatorname{hire}(\psi)=\alpha[1-(1-\psi) \operatorname{emp}(\psi)], \\
& \operatorname{sep}(\psi)=[\psi+\delta(1-\psi)] \operatorname{emp}(\psi) .
\end{aligned}
$$

where we highlighted the fact that the employed, hired and separated workers masses depend on the fraction of quitters $\psi$.

Differentiating the expressions above with respect to $\psi$ we get

$$
\begin{aligned}
& \frac{\mathrm{demp}(\psi)}{\mathrm{d} \psi}=\frac{-\alpha(1-\delta-\alpha)}{[1-(1-\delta-\alpha)(1-\psi)]^{2}}, \\
& \frac{\mathrm{d} h i r e(\psi)}{\mathrm{d} \psi}=\left(\frac{\alpha}{1-(1-\delta-\alpha)(1-\psi)}\right)^{2}, \\
& \frac{\mathrm{d} \operatorname{sep}(\psi)}{\mathrm{d} \psi}=\left(\frac{\alpha}{1-(1-\delta-\alpha)(1-\psi)}\right)^{2} .
\end{aligned}
$$

From those expressions we can see that hires and separations masses vary positively with changes in the fraction of quitters. Further, for $\delta, \alpha>0$ and $\delta+\alpha>0$, the employment mass in the steady state responds to variations in the fraction of quitters in their opposite way. Importantly, the $\alpha$ 's and $\delta$ 's of every age-skill cell satisfy this condition.

Write the turnover rate in steady state in terms of the employed, hired and separated workers masses. That is,

$$
\operatorname{turnover}(\psi)=\frac{\operatorname{hire}(\psi)+\operatorname{sep}(\psi)}{\operatorname{emp}(\psi)} .
$$

Differentiating the latter expression with respect to the fraction of quitters $\psi$, gives

$$
\frac{\mathrm{d} \text { turnover }}{\mathrm{d} \psi}=\frac{\frac{\mathrm{d}[\text { hire }+ \text { sep }]}{\mathrm{d} \psi} e m p-[\text { hire }+ \text { sep }] \frac{\mathrm{d} e m p}{\mathrm{~d} \psi}}{\left(\frac{\mathrm{d} e m p}{\mathrm{~d} \psi}\right)^{2}}
$$

where we have suppressed the $\psi$ argument for better exposition. The denominator is obviously positive. In the numerator, the left term is positive by what was developed earlier. The derivative in the right term was developed before 
and is negative for the parameter values we use. In result, the turnover rate responds positively to variations in the fraction of workers who quit their jobs.

Finally, to understand what could make $\psi$ vary, define the function $\mathrm{R}: \mathbb{R}_{+}^{2} \rightarrow \mathbb{R}$, such that $\mathrm{V}(w, t, R(w, t))=\mathrm{Q}(w, t)$. We do not formalize its existence, but provide a heuristic argument for the proof. Basically, $\mathrm{V}(w, t, \varepsilon)$ is strictly monotonic in $\varepsilon$ while $\mathrm{Q}(w, t)$ is invariant. So, for finite values of $V$ and $Q, R(w, t)$ will always be well defined.

The probability of a particular employed worker with an initial wage offer $w$ and job tenure $t$ quit is $F_{\varepsilon}(R(w, t))$. The sum of these probabilities over the $(\mathrm{w}, \mathrm{t})$ pairs of all employed workers divided by total employment gives the average probability of an employed worker quit. Any change that alters the wage or job tenure distribution of the employed workers, can modify this probability and if so, will end up changing the turnover rate as well. 